\title{
Article \\ The 'Green' Ni-UGSO Catalyst for Hydrogen Production under Various Reforming Regimes
}

\author{
Mostafa Chamoumi and Nicolas Abatzoglou *[D \\ Department of Chemical Engineering and Biotechnological Engineering, Université de Sherbrooke, 2500, \\ Boulevard de 1'Université, Sherbrooke, QC J1K 2R1, Canada; Mostafa.Chamoumi@usherbrooke.ca \\ * Correspondence: Nicolas.Abatzoglou@usherbrooke.ca; Tel.: +1-819-821-7904
}

check for updates

Citation: Chamoumi, M.; Abatzoglou, N. The 'Green' Ni-UGSO Catalyst for Hydrogen Production under Various Reforming Regimes. Catalysts 2021, 11, 771. https:// doi.org/10.3390/catal11070771

Academic Editors: Woohyun Kim and Kyubock Lee

Received: 17 May 2021

Accepted: 23 June 2021

Published: 25 June 2021

Publisher's Note: MDPI stays neutral with regard to jurisdictional claims in published maps and institutional affiliations.

Copyright: (c) 2021 by the authors. Licensee MDPI, Basel, Switzerland. This article is an open access article distributed under the terms and conditions of the Creative Commons Attribution (CC BY) license (https:/ / creativecommons.org/licenses/by/ $4.0 /)$.
Abstract: A new spinelized Ni catalyst (Ni-UGSO) using $\mathrm{Ni}\left(\mathrm{NO}_{3}\right)_{2} \cdot 6 \mathrm{H}_{2} \mathrm{O}$ as the $\mathrm{Ni}$ precursor was prepared according to a less material intensive protocol. The support of this catalyst is a negativevalue mining residue, UpGraded Slag Oxide (UGSO), produced from a $\mathrm{TiO}_{2}$ slag production unit. Applied to dry reforming of methane (DRM) at atmospheric pressure, $\mathrm{T}=810^{\circ} \mathrm{C}$, space velocity of $3400 \mathrm{~mL} / \mathrm{h} \cdot \mathrm{g})$ and molar $\mathrm{CO}_{2} / \mathrm{CH}_{4}=1.2$, Ni-UGSO gives a stable over $168 \mathrm{~h}$ time-on-stream methane conversion of $92 \%$. In this DRM reaction optimization study: (1) the best performance is obtained with the 10-13 wt\% Ni load; (2) the Ni-UGSO catalysts obtained from two different batches of UGSO demonstrated equivalent performances despite their slight differences in composition; (3) the sulfur-poisoning resistance study shows that at up to $5.5 \mathrm{ppm}$ no Ni-UGSO deactivation is observed. In steam reforming of methane (SRM), Ni-UGSO was tested at $900{ }^{\circ} \mathrm{C}$ and a molar ratio of $\mathrm{H}_{2} \mathrm{O} / \mathrm{CH}_{4}=1.7$. In this experimental range, $\mathrm{CH}_{4}$ conversion rapidly reached $98 \%$ and remained stable over $168 \mathrm{~h}$ time-on-stream (TOS). The same stability is observed for $\mathrm{H}_{2}$ and $\mathrm{CO}$ yields, at around $92 \%$ and $91 \%$, respectively, while $\mathrm{H}_{2} / \mathrm{CO}$ was close to 3 . In mixed (dry and steam) methane reforming using a ratio of $\mathrm{H}_{2} \mathrm{O} / \mathrm{CH}_{4}=0.15$ and $\mathrm{CO}_{2} / \mathrm{CH}_{4}=0.97$ for $74 \mathrm{~h}$ and three reaction temperature levels $\left(828{ }^{\circ} \mathrm{C}, 847{ }^{\circ} \mathrm{C}\right.$ and $\left.896^{\circ} \mathrm{C}\right), \mathrm{CH}_{4}$ conversion remains stable; $80 \%$ at $828^{\circ} \mathrm{C}$ $(26 \mathrm{~h}), 85 \%$ at $847{ }^{\circ} \mathrm{C}(24 \mathrm{~h})$ and $95 \%$ at $896^{\circ} \mathrm{C}(24 \mathrm{~h})$. All gaseous streams have been analyzed by gas chromatography. Both fresh and used catalysts are analyzed by scanning electron microscopyelectron dispersive X-ray spectroscopy (SEM-EDXS), X-ray diffraction (XRD), and thermogravimetric analysis (TGA) coupled with mass spectroscopy (MS) and BET Specific surface. In the reducing environment of reforming, such catalytic activity is mainly attributed to (a) alloys such as $\mathrm{FeNi}$, $\mathrm{FeNi}_{3}$ and $\mathrm{Fe}_{3} \mathrm{Ni}_{2}$ (reduction of $\mathrm{NiFe}_{2} \mathrm{O}_{4}, \mathrm{FeNiAlO}_{4}$ ) and (b) to the solid solution NiO-MgO. The latter is characterized by a molecular distribution of the catalytically active Ni phase while offering an environment that prevents $\mathrm{C}$ deposition due to its alkalinity.

Keywords: green nickel catalyst; Ni-UGSO; mining residue; spinel; basic support; solid solution; $\mathrm{NiO}-\mathrm{MgO}$; hydrogen; syngas; dry; steam and mixed reforming

\section{Introduction}

Several research works on nickel-based reforming catalysts are devoted to the development of their supports. The catalyst presented in this work valorizes a mining residue by using it as a support, allowing the production of renewable hydrogen from green catalysts and responding to the different spheres of sustainable development.

Worldwide, $\mathrm{H}_{2}$ is produced mainly from hydrocarbons using steam reforming of methane (SRM) (Reaction (R1)). Partial oxidation (POX) (Reaction (R2)) or dry reforming (DRM) (Reaction (R3)) are good candidates too. However, their use in the industry is limited due to certain drawbacks, namely, the relatively fast catalyst deactivation [1].

$$
\begin{array}{rlrl}
\mathrm{CH}_{4}+\mathrm{H}_{2} \mathrm{O} & \leftrightarrow \mathrm{CO}+3 \mathrm{H}_{2} & \left(\Delta \mathrm{H}^{\circ}{ }_{298}=206 \mathrm{MJ} / \mathrm{kmol}\right) \\
\mathrm{CH}_{4}+1 / 2 \mathrm{O}_{2} \leftrightarrow \mathrm{CO}+2 \mathrm{H}_{2} & \left(\Delta \mathrm{H}^{\circ}{ }_{298}=-38 \mathrm{MJ} / \mathrm{kmol}\right)
\end{array}
$$




$$
\mathrm{CH}_{4}+\mathrm{CO}_{2} \leftrightarrow 2 \mathrm{CO}+2 \mathrm{H}_{2} \quad\left(\Delta \mathrm{H}_{298}^{\circ}=247 \mathrm{MJ} / \mathrm{kmol}\right)
$$

SRM is the largest scale process for the production of $\mathrm{H}_{2}$ by natural gas conversion. $\mathrm{CH}_{4}$ is converted with steam on supported $\mathrm{Ni}$ catalysts in a highly endothermic reaction. The SRM reaction is conducted in heated tubular reactors to achieve the high temperatures needed, making steam reforming a major energy consumer.

Secondary reactions of carbon deposition also occur such as:

$$
\begin{aligned}
& 2 \mathrm{CO} \leftrightarrow \mathrm{C}+\mathrm{CO}_{2} \quad \text { Boudouard } \\
& \mathrm{CH}_{4} \leftrightarrow \mathrm{C}+2 \mathrm{H}_{2} \quad \mathrm{CH}_{4} \text { dissociation } \\
& \mathrm{H}_{2}+\mathrm{CO} \leftrightarrow \mathrm{C}+\mathrm{H}_{2} \mathrm{O} \quad \mathrm{H}_{2} \mathrm{O} \text { production } \\
& 2 \mathrm{H}_{2}+\mathrm{CO}_{2} \leftrightarrow \mathrm{C}+2 \mathrm{H}_{2} \mathrm{O} \quad \mathrm{H}_{2} \mathrm{O} \text { production }
\end{aligned}
$$

An excess of water makes it possible to drive Reaction (R6) towards the formation of synthesis gas and minimize carbon formation. In fact, by reacting $\mathrm{CO}$ with $\mathrm{H}_{2} \mathrm{O}$ according to the water-gas-shift (WGS) Reaction (R8), the $\mathrm{CO}$ becomes $\mathrm{CO}_{2}$, thus producing more hydrogen and increasing the $\mathrm{H}_{2} / \mathrm{CO}$ ratio:

$$
\mathrm{CO}+\mathrm{H}_{2} \mathrm{O} \leftrightarrow \mathrm{CO}_{2}+\mathrm{H}_{2} \quad\left(\Delta \mathrm{H}^{\circ}{ }_{298}=-41 \mathrm{MJ} / \mathrm{kmol}\right)
$$

Because the SRM reaction is endothermic, it requires high-temperature conditions ( $\mathrm{T}>800{ }^{\circ} \mathrm{C}$ ) to increase conversion and decrease carbon formation while increasing $\mathrm{H}_{2}$ and $\mathrm{CO}$ yields. Relatively high working pressures (20-40 bar) are also used industrially $[2,3]$. This process, despite its importance, has the major disadvantage of being energy-intensive, a situation which is made worse by the use of excess water.

In the catalytic POX (Reaction (R2)), $\mathrm{CH}_{4}$ is converted with oxygen or air to form $\mathrm{H}_{2}$ and $\mathrm{CO}$ with a ratio of $\mathrm{H}_{2} / \mathrm{CO}=2$. This ratio of 2 is ideal for most downstream processes, making partial oxidation of methane a simple, one-step process. Unlike SRM, the POX of methane is slightly exothermic.

In the last decades, the constant development of DRM (Reaction (R3)) is mainly due to:

(a) the use 2 GHGs $\left(\mathrm{CH}_{4}\right.$ and $\left.\mathrm{CO}_{2}\right)$; the technology is under study and making its first steps at industrial demonstration scale [4];

(b) the production of a valuable syngas $\left(\mathrm{CO}+\mathrm{H}_{2}\right)$ with a molar $\mathrm{H}_{2} / \mathrm{CO}=1$, which is essential, among other things, for the production of methanol and wax according to Fischer-Tropsch [5,6]. More recently, Topsoe developed a technology, called ReShift ${ }^{\mathrm{TM}}$ that uses a significant amount of $\mathrm{CO}_{2}$ for making synthesis gas (syngas; $\mathrm{H}_{2}+\mathrm{CO}$ ) without the traditional challenge of carbon formation [7].

$\mathrm{DRM}$, being an endothermic reaction, requires high temperatures (higher than $650{ }^{\circ} \mathrm{C}$ ). Otherwise, the side reactions below may take place [8].

$$
\begin{array}{cc}
\mathrm{CO}_{2}+\mathrm{H}_{2} \leftrightarrow \mathrm{CO}+\mathrm{H}_{2} \mathrm{O} & \text { Reverse WGS } \\
2 \mathrm{CO} \leftrightarrow \mathrm{C}+\mathrm{CO}_{2} & \text { Boudouard } \\
\mathrm{CH}_{4} \leftrightarrow \mathrm{C}+2 \mathrm{H}_{2} & \mathrm{CH}_{4} \text { dissociation } \\
\mathrm{C}+\mathrm{H}_{2} \mathrm{O} \leftrightarrow \mathrm{CO}+\mathrm{H}_{2} & \text { C gasification }
\end{array}
$$

The production of hydrogen $\mathrm{H}_{2}$ by reforming reactions mainly uses Ni-based catalysts under conditions that prevent their deactivation by the formation of carbon (C) [9-12]. Carbon formation results mainly from the Boudouard reaction (Reaction (R4)) and the decomposition of $\mathrm{CH}_{4}$ (Reaction (R5)) [10,13].

One way to overcome the drawback of coking is the strong interaction between the active metal $(\mathrm{Ni})$ and the support that prevents the formation of carbon and the sintering of $\mathrm{Ni}$ [14]. 
For catalysts supported by alumina $\left(\mathrm{Al}_{2} \mathrm{O}_{3}\right)$, the spinel phase formed $\left(\mathrm{NiAl}_{2} \mathrm{O}_{4}\right)$ allows high conversion of $\mathrm{CH}_{4}$ with low formation of $\mathrm{C}$ during SRM reactions [15]. Likewise, the nickel-alumina spinel catalyst supported on alumina and yttria-stabilized zirconia $\left(\mathrm{NiAl}_{2} \mathrm{O}_{4}-/ \mathrm{Al}_{2} \mathrm{O}_{3}-\mathrm{YSZ}\right)$, developed by our research group, has demonstrated significant resistance to poisoning when compared to standard $\mathrm{Ni} / \mathrm{Al}_{2} \mathrm{O}_{3}-\mathrm{YSZ}$ formulations in the case of diesel steam reforming [16-18].

The addition of promoters in the formulation of the catalyst has also been the subject of several research studies [19-21]. Luna et al. [22] studied the effect of K, Ca, Sn and Mn on a $\mathrm{Ni} / \mathrm{Al}_{2} \mathrm{O}_{3}$ catalyst. The authors indicated that the presence of $\mathrm{K}$ improved the stability significantly with a slight decrease in activity after $30 \mathrm{~h}$ of TOS. Siahvashi et al. [23] studied the DR of propane and showed that the addition of $\mathrm{K}$ to the Ni-Mo catalyst supported by $\mathrm{Al}_{2} \mathrm{O}_{3}$ increased the $\mathrm{CO}$ yield with a significant decrease in carbon deposition.

In addition, several studies have shown the beneficial effect of the basicity of supports. Thus, the addition of $\mathrm{MgO}$ to a $\mathrm{Ni} / \mathrm{Al}_{2} \mathrm{O}_{3}$ catalyst improved the stability of the catalyst at high temperatures by forming $\mathrm{MgAl}_{2} \mathrm{O}_{4}$ spinel. The strong adsorption of $\mathrm{CO}_{2}$ on the basic surface of $\mathrm{MgO}$ is considered the main mechanism of carbon formation prevention [24]. The work carried out by Ranjbar et al. [25], on the addition of Ca, shows an increase in the activity of the catalyst and its resistance to carbon deposition.

Rio Tinto Iron and Titanium (RTIT), a wholly-owned subsidiary of Rio Tinto, has been operating for several years at the Tio mine, the largest ilmenite deposit $\left(\mathrm{FeTiO}_{3}\right)$ in the world, located $43 \mathrm{~km}$ northeast of Havre-Saint-Pierre, Quebec. A world leader in the industry, RTIT has developed and implemented a proprietary process called UpGraded Slag (UGS) on the site of the Sorel-Tracy metallurgical complex (Quebec). UGS produces titanium slag with the highest $\mathrm{TiO}_{2}$ content $(94.5 \%)$ on the market from the Ilmenite of the North Shore. However, this process generates a large amount of UGS oxide residue (noted UGSO), sent directly to the tailings deposit to end up in the landfill. Concerned by the accumulation of large quantities of this residue and the importance of its footprint, RTIT has for several years made significant efforts to find other solutions. Avoiding depositing these UGSOs in landfill tailings ponds by upgrading them has become a major and urgent challenge.

This waste, whose chemical composition has been presented in our previous paper [26] has been considered an excellent nickel-based catalyst support candidate. Indeed, UGSO already contains oxides recognized for their ability to avoid carbon formation, the main cause of these catalysts' deactivation.

In our previous papers [26-28], we have developed a simple and easy solid-state method of preparing a new generation of Ni-UGSO catalyst using UGSO as a support and $\mathrm{Ni}$ as the active metal.

The first results obtained, when applying the Ni-UGSO to DRM, show good catalytic performances with no carbon deposit [26].

The objective of this work consists of, on the one hand, an optimization of the DRM, and on the other hand, the study of the catalytic activity of this new Ni-UGSO catalyst in other types of $\mathrm{CH}_{4}$ reforming, namely SRM, mixed (dry and steam) methane reforming and its sulfur-poisoning resistance. In this work, Ni-UGSO BT designates the fresh catalyst before treatment reforming (BT) and Ni-UGSO AT designates the catalyst after treatment reforming.

\section{Results}

\subsection{Characterization of Fresh Catalysts Ni-UGSO BT}

As presented in our previous article [26], by ICP-MS analysis, the Ni-UGSO BT catalyst shows a Ni content of $13.9 \pm 1.6 \mathrm{wt} \%$; BET analysis gave a specific surface area of $3.94 \pm 0.26 \mathrm{~m}^{2} / \mathrm{g}$ and SEM analyses have shown that the catalyst particles have a lamellar morphology and average size of $168 \pm 59 \mathrm{~nm}$.

Compared to oxide residue before testing (UGSO-BT), XRD patterns [26] of the new catalyst sample before catalytic testing (Ni-UGSO-BT) showed, in addition to the spinel 
peaks present in UGSO-BT, the appearance of new peaks corresponding to Ni-based spinels $\left(\mathrm{NiFe}_{2} \mathrm{O}_{4}\right.$ and $\left.\mathrm{FeNiAlO}_{4}\right)$. XRD patterns also showed three other components at the same $2 \theta=37.31,43.30,63.40,75.5$ and $79.1^{\circ}$ [26]. These peaks corresponded to the remaining $\mathrm{MgO}, \mathrm{NiO}$, and solid solution $\mathrm{NiO}-\mathrm{MgO}$. These results agree with those of Requies et al. [29], who study the partial oxidation of methane; the diffraction patterns of $\mathrm{Ni} / \mathrm{MgO}$ catalysts containing 20 and $30 \mathrm{wt} \%$ showed the formation of a solid solution between $\mathrm{NiO}$ and $\mathrm{MgO}$ at $2 \theta$ of 37.2, 43.1, 62.6, 75.0 and 78.9 .

\subsection{Thermodynamics of DRM and SMR Reactions}

$\mathrm{CH}_{4}$ and $\mathrm{CO}_{2}$ conversions (DRM), $\mathrm{CH}_{4}$ and $\mathrm{H}_{2} \mathrm{O}$ conversion (SRM), and the thermodynamic equilibrium composition of the products, under a pressure of $1 \mathrm{~atm}$, were calculated using the FactSage 7.3 software (FactSage 7.3; Thermfact/CRCT, Montreal, QC, Canada; www.crct.polymtl.ca and GTT-Technologies, Aachen, Germany, www.gtt-technologies.de; 2019). Full data from the thermodynamic study are provided in Part A of the Supplementary Materials.

The study showed that, at thermodynamic equilibrium, starting at $850{ }^{\circ} \mathrm{C}$, the DRM reaction showed a molar ratio of $\mathrm{H}_{2} / \mathrm{CO}=1$ and conversion rates of $97 \%$ for $\mathrm{CH}_{4}$ and $95 \%$ for $\mathrm{CO}_{2}$. However, it was only at or above $950{ }^{\circ} \mathrm{C}$ that the formation of carbon was fully inhibited.

The SRM reaction showed, at or above $850{ }^{\circ} \mathrm{C}$, a molar ratio of $\mathrm{H}_{2} / \mathrm{CO}=3$ and $\mathrm{CH}_{4}$ and $\mathrm{H}_{2} \mathrm{O}$ conversion rates of $94 \%$ and $95 \%$, respectively. At or above this temperature $\left(850^{\circ} \mathrm{C}\right)$, carbon formation no longer occurred.

Taking all presented data into consideration, it would be more reasonable to study the catalytic performance of the Ni-UGSO catalyst in the temperature range of $800-900{ }^{\circ} \mathrm{C}$, where conversion was practically complete and carbon formation was still marginally thermodynamically possible.

\subsection{Ni-UGSO Performance as a Catalyst for DRM}

\subsubsection{Experimental Evaluation of Catalyst Activity and Stability}

In the DRM of our previous work [26], a molar $\mathrm{CO}_{2} / \mathrm{CH}_{4}$ was heated at $810^{\circ} \mathrm{C}$ in the presence of $0.3 \mathrm{~g}$ of catalyst. A comparison of the catalytic activity of Ni-UGSO $\left(\mathrm{Q}_{\mathrm{CO} 2}=\right.$ $7.08 \mathrm{~mL} / \mathrm{min}, \mathrm{Q}_{\mathrm{CH} 4}=7.26 \mathrm{~mL} / \mathrm{min}$ and GHSV $\left.=2867 \mathrm{~mL} /(\mathrm{h} \cdot \mathrm{g})\right)$ with $\mathrm{UGSO}\left(\mathrm{Q}_{\mathrm{CO} 2}=7.63\right.$ $\mathrm{mL} / \mathrm{min}, \mathrm{Q}_{\mathrm{CH} 4}=7.35 \mathrm{~mL} / \mathrm{min}$ and GHSV $\left.=2996 \mathrm{~mL} /(\mathrm{h} \cdot \mathrm{g})\right)$ showed that a maximum $\mathrm{CH}_{4}$ conversion of $30 \%$ was obtained after 30 min of reaction in the presence of UGSO, which gradually decreased and reached $18 \%$ after $4 \mathrm{~h}$ of reaction. Under the same experimental conditions in the presence of the new Ni-UGSO catalyst, the conversion of $\mathrm{CH}_{4}$ quickly reached $87 \%$ and remains stable during the $4 \mathrm{~h}$ of reaction.

Activity and stability of the new Ni-UGSO catalyst were assessed for 7 days of DRM in the same conditions as above at a molar ratio of $\mathrm{CO}_{2} / \mathrm{CH}_{4}=1.2\left(\mathrm{Q}_{\mathrm{CO} 2}=9.30 \mathrm{~mL} / \mathrm{min}\right.$ and $\mathrm{Q}_{\mathrm{CH} 4}=7.76 \mathrm{~mL} / \mathrm{min}$ and $\left.\mathrm{GHSV}=3412 \mathrm{~mL} /(\mathrm{h} \cdot \mathrm{g})\right)$ [26]. $\mathrm{CH}_{4}$ conversion rapidly reached $92 \%$ and remains stable over $168 \mathrm{~h}$ TOS. The same stability was observed for $\mathrm{H}_{2}$ and $\mathrm{CO}$ yields, which were at around $82 \%$ and $87 \%$, respectively, with a molar $\mathrm{H}_{2} / \mathrm{CO}$ ratio close to 1 , which was closer to the thermodynamic equilibrium. An activity loss of approximately $5 \%$ over seven days TOS was observed.

The various techniques for characterizing spent catalysts (XRD, SEM-EDX, XPS, TGAMS) showed no carbon deposition.

\subsubsection{Influence of the Active Phase Content on the Catalytic Activity}

This study aimed to optimize the content of the active phase (Ni) necessary to carry out the DRM while obtaining a suitable conversion. Five nickel mass contents were chosen: $3 \%, 6 \%, 9 \%, 10 \%$ and $13 \%$. Catalysts were calcined at $900{ }^{\circ} \mathrm{C}$ for $12 \mathrm{~h}$. The DRM reaction was carried out at $840^{\circ} \mathrm{C}$ with a $\mathrm{CO}_{2} / \mathrm{CH}_{4}$ ratio of $1.25\left(\mathrm{Q}_{\mathrm{CO} 2}=9.62 \mathrm{~mL} / \mathrm{min}\right.$ and $\mathrm{Q}_{\mathrm{CH} 4}=$ $7.71 \mathrm{~mL} / \mathrm{min}$ ) without Ar and a GHSV of $3500 \mathrm{~mL} /$ (h.gcat). 
Figure 1 shows the evolution of $\mathrm{CH}_{4}$ conversion along the reforming tests. Part $\mathrm{B}$ of the supplementary information presents figures of $\mathrm{CO}_{2}$ conversions (Figure S6, Supplementary Materials), $\mathrm{H}_{2}$ yield (Figure S7, Supplementary Materials) and the $\mathrm{H}_{2} / \mathrm{CO}$ ratio (Figure S8, Supplementary Materials).

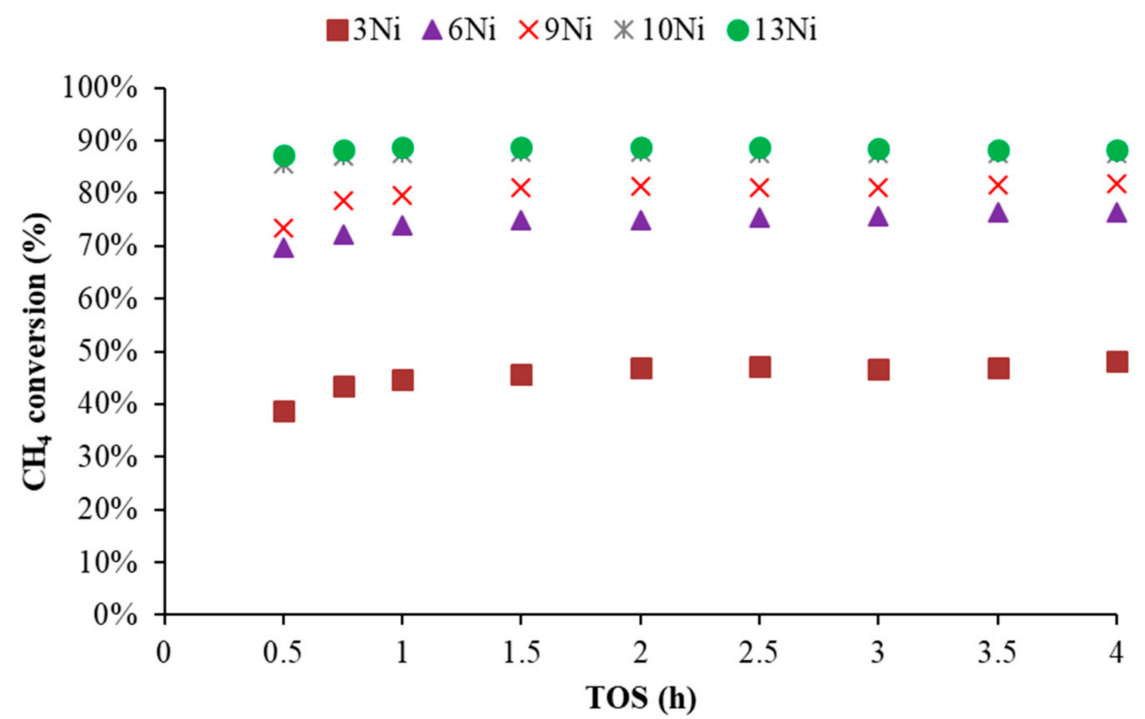

Figure 1. Effect of Ni content: evolution of $\mathrm{CH}_{4}$ conversion as a function of time $\left(\mathrm{CO}_{2} / \mathrm{CH}_{4}=1.25\right.$, $842{ }^{\circ} \mathrm{C}$, Catalysts are calcined at $900{ }^{\circ} \mathrm{C}$ for $12 \mathrm{~h}$ ).

At 3\% Ni, the catalyst had the lowest catalytic activity compared to the others because the $\mathrm{CH}_{4}$ and $\mathrm{CO}_{2}$ conversions did not exceed $50 \%$ and $60 \%$. The same applied to the $\mathrm{H}_{2}$ yield, which was in the order of $65 \%$. The best performance was obtained with the $10 \% \mathrm{Ni}$ catalyst; it was equivalent to the performance of the $13 \% \mathrm{Ni}$ catalyst. The data obtained from $\mathrm{H}_{2} / \mathrm{CO}(0.5)$ and $\mathrm{X}-\mathrm{CO}_{2} / \mathrm{X}-\mathrm{CH}_{4}$ (1.3) conversion rates indicated the significant role of the reverse-water-gas-shift (RWGS) reaction. However, these two ratios tended towards thermodynamic values $\left(\mathrm{H}_{2} / \mathrm{CO}=1, \mathrm{X}-\mathrm{CO}_{2} / \mathrm{X}-\mathrm{CH}_{4}=1\right)$ as the Ni content increased.

These results corroborated those obtained from the XRD analyses (Figure 2), where the intensity of the peaks attributed to different species of $\mathrm{Ni}$ oxides (spinel $\mathrm{NiFe}_{2} \mathrm{O}_{4}, \mathrm{FeNiAlO}_{4}$ and solid solution $\mathrm{NiO}-\mathrm{MgO}$ (red arrow) was a function of the $\mathrm{Ni}$ content.

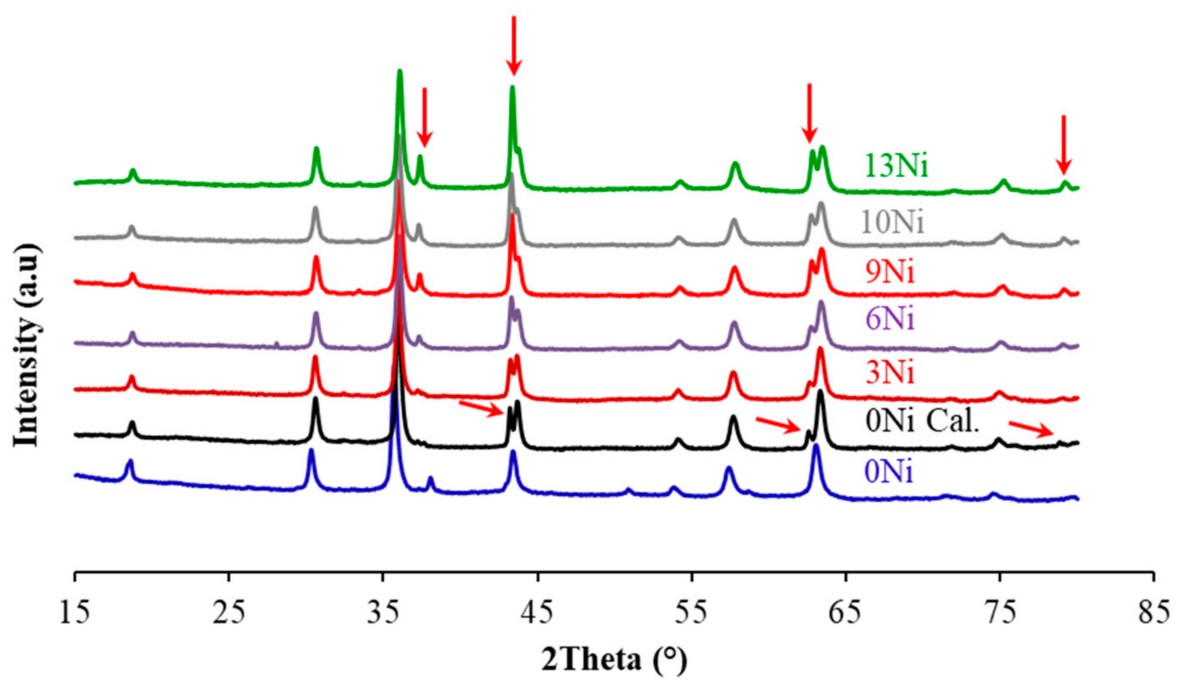

Figure 2. XRD of catalysts as a function of Ni content. 
Average catalyst surface BET as a function of Ni-loading (Table 1) shows that the BET decreased slightly as a function of Ni-loading. This could be due to some agglomeration of the particles. The same was also observed on the UGSO support (without Ni), whose surface area decreased from $38 \mathrm{~m}^{2} / \mathrm{g}$ to $6 \mathrm{~m}^{2} / \mathrm{g}$ after calcination at $900{ }^{\circ} \mathrm{C}$ for $12 \mathrm{~h}$.

Table 1. Average catalyst surface BET as function of Ni-loading.

\begin{tabular}{cccccc}
\hline $\mathbf{N i}(\mathbf{w t} \%)$ & $\mathbf{3}$ & $\mathbf{6}$ & $\mathbf{9}$ & $\mathbf{1 0}$ & $\mathbf{1 3}$ \\
\hline $\mathrm{S}_{\mathrm{BET}}\left(\mathrm{m}^{2} / \mathrm{g}\right)$ & $5.4 \pm 0.5$ & $5.0 \pm 0.2$ & $4.5 \pm 0.2$ & $4.4 \pm 0.4$ & $3.8 \pm 0.4$ \\
\hline
\end{tabular}

Figure 3 below shows SEM photos of the Ni-UGSO catalyst as a function of Ni-loading. These figures show that, whatever the Ni content, the particles kept their lamellar shape.
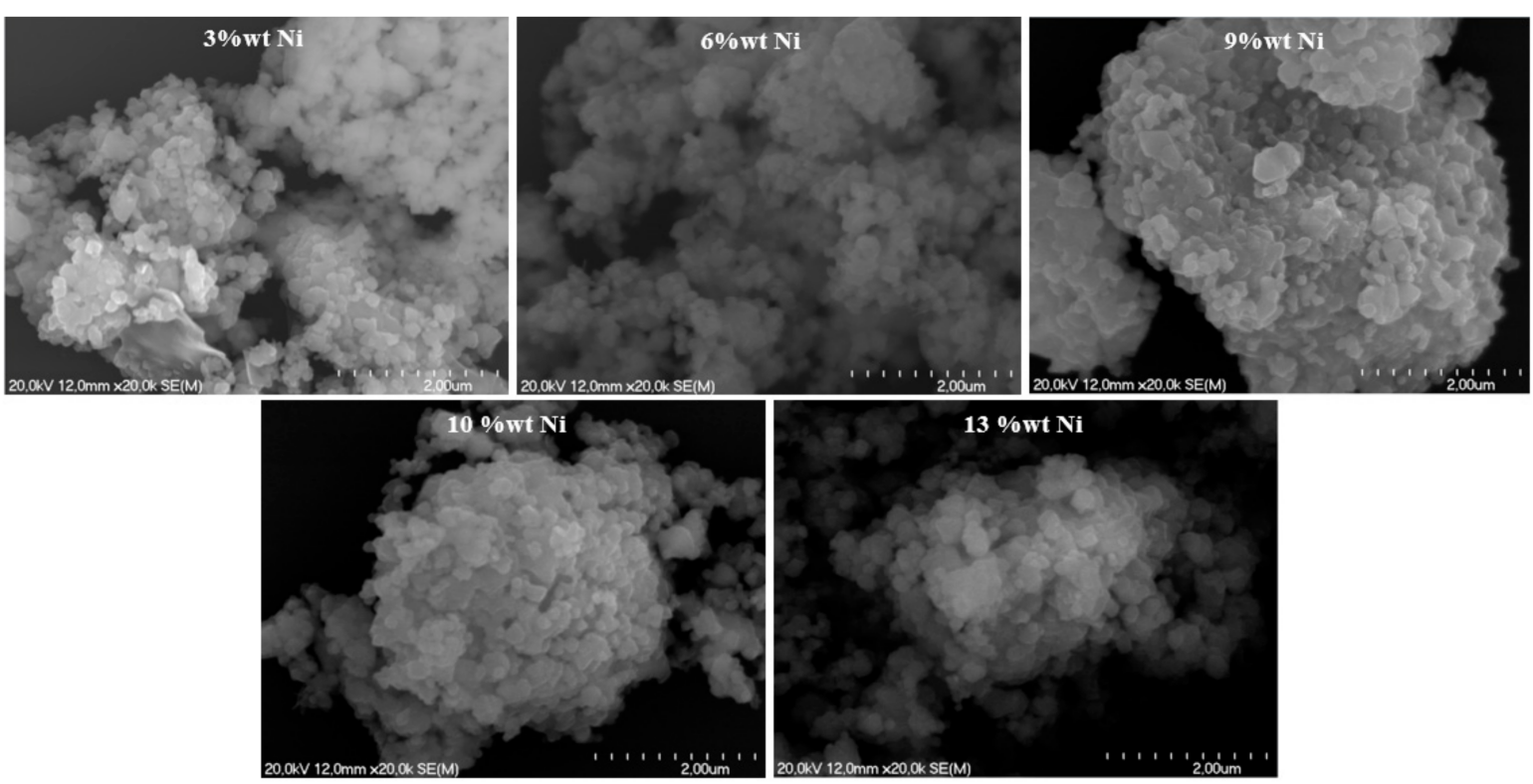

Figure 3. SEM photos of the Ni-UGSO catalyst as a function of Ni-loading.

The mapping study shows, in all cases, a good dispersion of the Ni (Figure S9, Supplementary Materials).

\subsubsection{Influence of Catalyst Calcination Time}

Three catalysts were obtained by calcination at $900{ }^{\circ} \mathrm{C}$ for $1 \mathrm{~h}, 3 \mathrm{~h}$ and $12 \mathrm{~h}$. The catalytic performances of these three solids was studied with $0.3 \mathrm{~g}$ of Ni-UGSO catalyst at $840{ }^{\circ} \mathrm{C}$ using a $\mathrm{CO}_{2} / \mathrm{CH}_{4}$ molar ratio $=1.2\left(\mathrm{Q}_{\mathrm{CO} 2}=9.75 \mathrm{~mL} / \mathrm{min}\right.$ and $\left.\mathrm{Q}_{\mathrm{CH} 4}=8.20 \mathrm{~mL} / \mathrm{min}\right)$ without Ar. The results obtained, presented in Figure 4, showed that the performances of the catalyst calcined for $3 \mathrm{~h}$ at $900{ }^{\circ} \mathrm{C}$ was similar to that of the catalyst treated for $12 \mathrm{~h}$ at the same temperature. Moreover, the catalyst with $1 \mathrm{~h}$ of heat treatment at $900{ }^{\circ} \mathrm{C}$ gave the best performance. Consequently, $1 \mathrm{~h}$ of calcination would be sufficient to obtain a catalyst giving $\mathrm{CH}_{4}$ conversions exceeding $95 \%$.

Examination of the XRDs of these catalysts (Figure S10, Supplementary Materials) indicated that the longer the calcination time, the more the peaks at $2 \theta=43^{\circ}$ and $63^{\circ}$ (two of the four representative peaks of the catalyst) became sharper. These indications and those of the specific surfaces presented in Table 2 went in the same direction, thus confirming the effect of prolonged exposure of the catalyst to the heat treatment on particle size. The best performances obtained by the catalyst calcined for $1 \mathrm{~h}$ was, therefore, related to its higher specific surface area compared to the other two. This is an important result because it is related to the energy consumption during the eventual commercial manufacturing of the catalyst. 


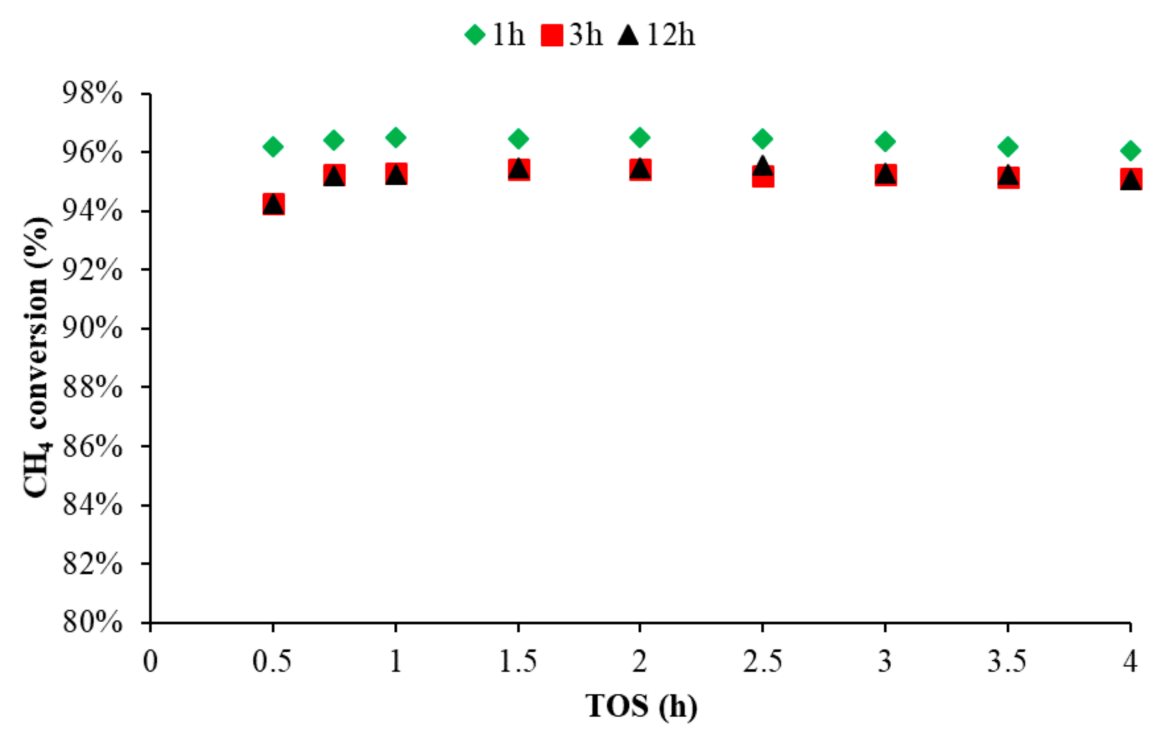

Figure 4. Effect of calcination time of Ni-UGSO catalyst with $13 \% \mathrm{Ni}(\mathrm{wt} \%)$ : evolution of $\mathrm{CH}_{4}$ conversion as a function of time $\left(\mathrm{CO}_{2} / \mathrm{CH}_{4}=1.2,840^{\circ} \mathrm{C}\right)$.

Table 2. Average catalyst surface BET as function of calcination time of Ni-UGSO catalyst with $13 \%$ $\mathrm{Ni}(\mathrm{wt} \%)$.

\begin{tabular}{cccc}
\hline Cal. Time (h) & $\mathbf{1}$ & $\mathbf{3}$ & $\mathbf{1 2}$ \\
\hline $\mathrm{S}_{\mathrm{BET}}\left(\mathrm{m}^{2} / \mathrm{g}\right)$ & $5.0 \pm 0.2$ & $4.7 \pm 0.2$ & $3.8 \pm 0.4$ \\
\hline
\end{tabular}

\subsubsection{Representativeness of UGSO Mining Residue Lots}

A second batch (L2) of UGSO was compared with the first (L1) to evaluate the impact of a variation of the UGSO composition on the Ni-UGSO catalyst performance.

As shown in Table 3, the ICP-MS analysis shows that the constitutive elements of the residue remain unchanged despite the variation in their contents. The balance is oxygen.

Table 3. ICP-MS analysis of two batches of UGSO (wt\%).

\begin{tabular}{lccccccccc}
\hline & $\mathbf{F e}$ & $\mathbf{M g}$ & $\mathbf{A l}_{\mathbf{3}}$ & $\mathbf{C a}$ & $\mathbf{M n}$ & $\mathbf{V}_{\mathbf{5}}$ & $\mathbf{T i}_{\mathbf{2}}$ & $\mathbf{C r}$ & $\mathbf{Z n}$ \\
\hline UGSO-L1 & 31.11 & 17.98 & 5.23 & 1.28 & 1.68 & 1.46 & 0.49 & 0.47 & 0.01 \\
UGSO-L2 & 34.04 & 21.09 & 6.84 & 1.58 & 1.82 & 1.71 & 0.52 & 0.56 & 0.01 \\
Variation & $9.44 \%$ & $17.32 \%$ & $30.70 \%$ & $24.13 \%$ & $8.24 \%$ & $16.74 \%$ & $5.38 \%$ & $18.50 \%$ & $0.00 \%$ \\
\hline
\end{tabular}

XRD patterns (Figure S11, Supplementary Materials) showed that, although the structures of UGSO-L1 and UGSO-L2 seemed different, UGSO-L2 was identical to that of the first batch calcined at $900{ }^{\circ} \mathrm{C} / 12 \mathrm{~h}$ (UGSO-L1_Cal.). This suggests that the second batch may have undergone additional calcination before its disposal in the RTIT Landfill [30]. It should be noted that only the L1 batch was slightly different in terms of phases. All other batches received subsequently had the same phases, and their calcination did not bring any change to the material, as shown by the calcination carried out on L3 (Figure S12, Supplementary Materials). Otherwise, despite the slight difference in composition, the catalytic activity of the different batches used in the reforming tests showed similar catalytic activities.

The corresponding Ni-UGSO-L1 and Ni-UGSO-L2 catalysts, both at $13 \% \mathrm{Ni}(\mathrm{wt} \%$ ), were prepared according to the same protocol of improved solid-state reaction and calcined at $900{ }^{\circ} \mathrm{C}$ for $1 \mathrm{~h}$. 
The XRDs of the two catalysts (Figure S13, Supplementary Materials) showed that both catalysts obtained by adding $\mathrm{Ni}$ as active metal had the same structure (a slight difference was observed for the peak at $2 \theta=63.45^{\circ}$ ).

The reforming reactions were carried out at $840{ }^{\circ} \mathrm{C}$ on $0.3 \mathrm{~g}$ of Ni-UGSO-L1 or L2 calcined for $1 \mathrm{~h}$ using a $\mathrm{CO}_{2} / \mathrm{CH}_{4}$ molar ratio $=1.2\left(\mathrm{Q}_{\mathrm{CO} 2}=9.45 \mathrm{~mL} / \mathrm{min}\right.$ and $\mathrm{Q}_{\mathrm{CH} 4}=7.68$ $\mathrm{mL} / \mathrm{min}$ ) without Ar and a GHSV $=3400 \mathrm{~mL} /(\mathrm{h} \cdot$ gcat). The results obtained (Figure 5) showed that the two catalysts had the same $\mathrm{CH}_{4}$ conversions. Despite a slight difference of the composition, the Ni-UGSO catalysts obtained from these two batches of tested residues demonstrated equivalent performance during DRM.

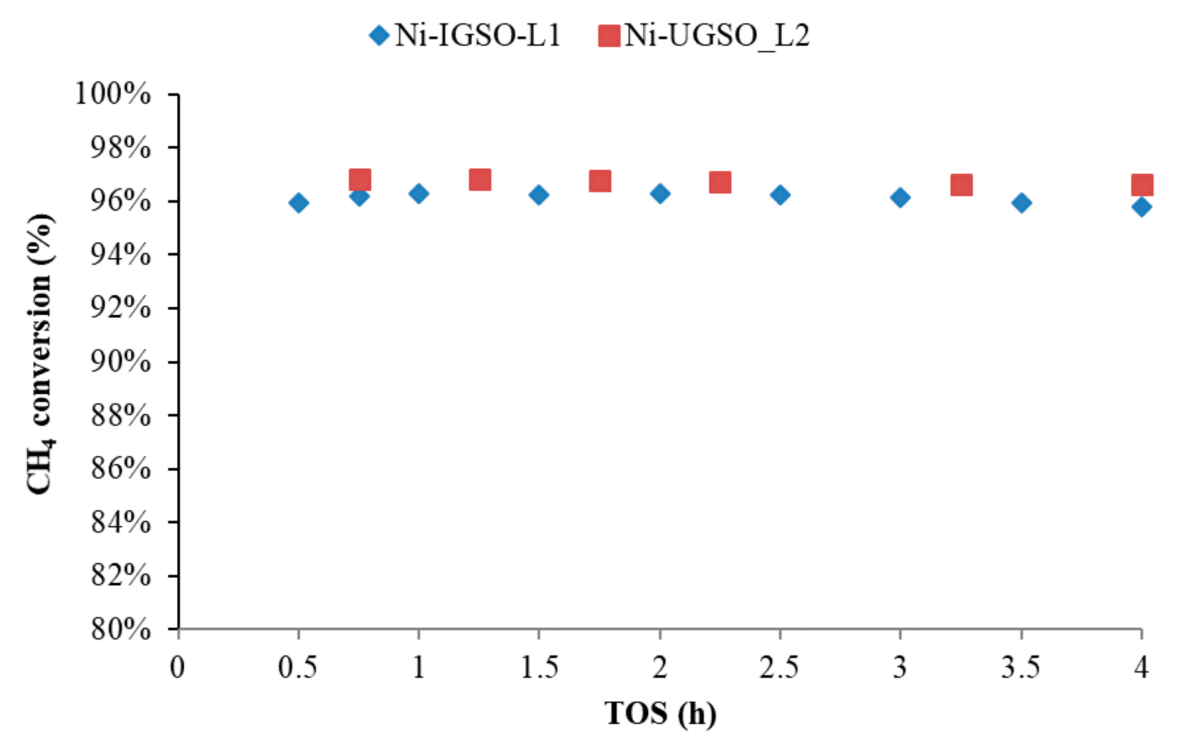

Figure 5. $\mathrm{CH} 4$ conversion over $\mathrm{TOS}$ at $840{ }^{\circ} \mathrm{C}, \mathrm{CO}_{2} / \mathrm{CH}_{4}=1.2$. for $1 \mathrm{~h}$.

Comparison of Ni-UGSO-L1 (batch 1) and Ni-UGSO-L2 (batch 2) calcined at $900{ }^{\circ} \mathrm{C}$

\subsubsection{Ni-UGSO Sulfur Poisoning Resistance}

$\mathrm{Ni}$-UGSO sulfur poisoning resistance was assessed for $5 \mathrm{~h}$ of DRM with a molar ratio of $\mathrm{CO}_{2} / \mathrm{CH}_{4}=0.96$ at $810{ }^{\circ} \mathrm{C}$ under $1.5 \mathrm{ppm}, 5.5 \mathrm{ppm}$ and $12 \mathrm{ppm}$ of $\mathrm{H}_{2} \mathrm{~S}$.

Up to $5.5 \mathrm{ppm}$, the catalyst showed no deactivation. A slight deactivation (3\%) was observed at $12 \mathrm{ppm}$ and remained stable throughout the $1 \mathrm{~h}$ exposure of the catalyst to $\mathrm{H}_{2} \mathrm{~S}$ at the reported concentrations (Figure 6).

As shown in the XRD of used catalysts (Figure S14, Supplementary Materials), the amount of $S$ was so low that the peaks corresponding to Ni-S were not detected. However, a more in-depth study of the resistance of Ni-UGSO to sulfides was carried out, by our group research, at higher concentrations (275 ppm of $\mathrm{H}_{2} \mathrm{~S}$ ) on dry autothermal ethane reforming [31]. XRD, BET, SEM and TGA analysis are used. XRD showed the formation of new phases such as NiFe, NiS and FeS. In TGA analysis, weight losses observed were attributed to the endothermal decomposition of $\mathrm{NiSO}_{4}$, which might be formed by oxidation of the NixSy species; this decomposition was described by the following equation: $\mathrm{NiSO}_{4}(\mathrm{~s})=\mathrm{NiO}(\mathrm{s})+\mathrm{SO}_{2}(\mathrm{~g})+\frac{1}{2} \mathrm{O}_{2}(\mathrm{~g})$. 


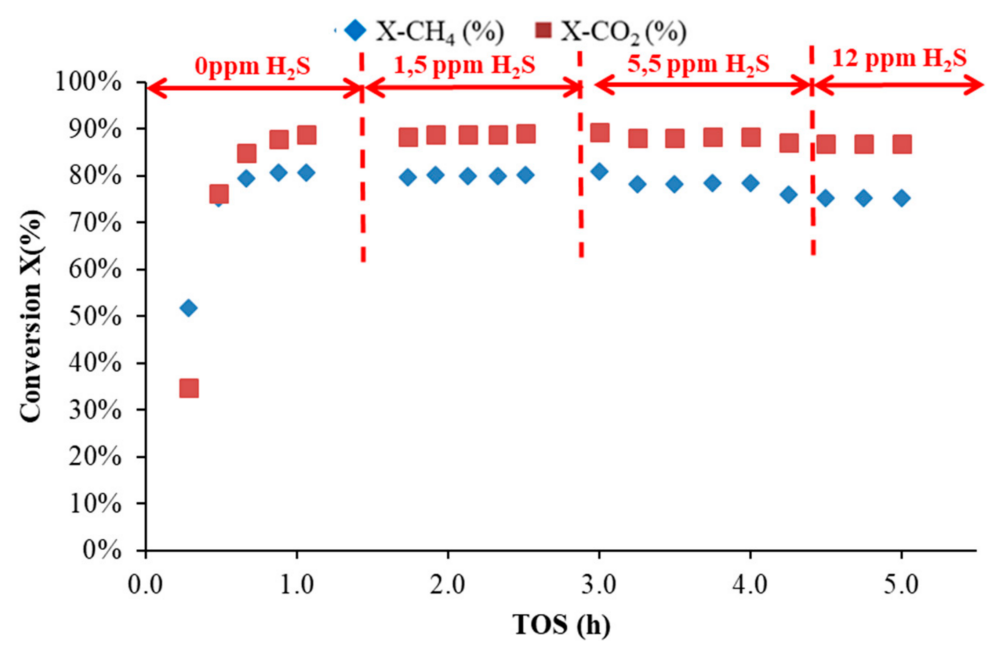

Figure 6. Catalytic performances of Ni-UGSO on DRM at low $\mathrm{H}_{2} \mathrm{~S}$ loads $\left(\mathrm{CO}_{2} / \mathrm{CH}_{4}=0.96,810^{\circ} \mathrm{C}\right)$.

\subsection{Ni-UGSO Performance as a Catalyst for SRM}

SRM on Ni-based catalysts is currently the only industrially used method for hydrogen production [32]. S/C ratios more than 3 [32] are used at the expense of energy to avoid catalyst deactivation by carbon deposition. The excess of steam is beneficial in gasifying a portion of the carbonaceous deposits on the catalyst surface and, therefore, improving the carbon gasification [32,33]. Nevertheless, the higher amounts of $\mathrm{H}_{2} \mathrm{O}$ also lead to an enrichment of the product in $\mathrm{H}_{2}$ due to the enhancing the WGS reaction.

$\mathrm{Ni}$-UGSO stability in SRM was evaluated for seven days at $900{ }^{\circ} \mathrm{C}$ with a molar ratio of $\mathrm{H}_{2} \mathrm{O} / \mathrm{CH}_{4}=1.7\left(\mathrm{Q}_{\mathrm{H} 2 \mathrm{O}}=13.94 \mathrm{~mL} / \mathrm{min}, \mathrm{Q}_{\mathrm{CH} 4}=8.20 \mathrm{~mL} / \mathrm{min}\right.$ and $\left.\mathrm{Q}_{\mathrm{Ar}}=17.15 \mathrm{~mL} / \mathrm{min}\right)$, well below industrial ratios.

The results obtained showed that, during the 7 days of reaction, $\mathrm{CH}_{4}$ conversion remained stable at around $98 \%$, with a molar $\mathrm{H}_{2} / \mathrm{CO}$ ratio in the products close to 3 . This is a clear indication that, at these experimental conditions, the reaction reached thermodynamic equilibrium (Figure 7).

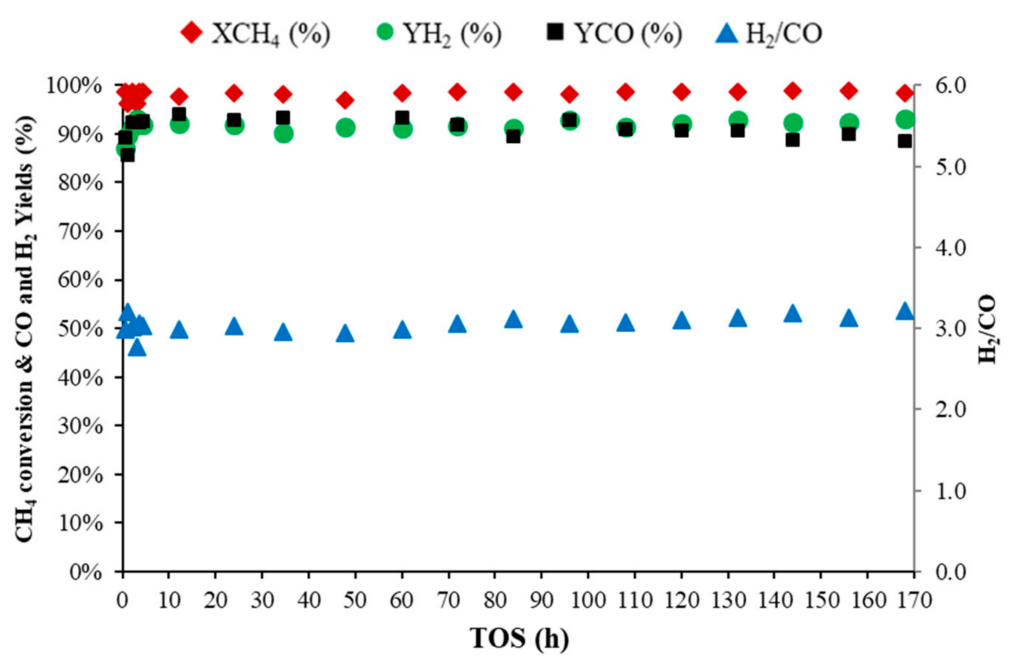

Figure 7. Catalytic performances of Ni-UGSO on SRM $\left(\mathrm{H}_{2} \mathrm{O} / \mathrm{CH}_{4}=1.7,900{ }^{\circ} \mathrm{C}\right)$.

It is important to note that no trace of carbon was detected on the spent catalyst, as shown by the XRD analysis (Figure S15, Supplementary Materials) and SEM-EDX analyses (Figure 8). It should also be noted that the small peak of carbon observed in the EDX of the spent catalyst (Ni-UGSO AT) was identical to that of the fresh catalyst (Ni-UGSO-BT). As mentioned in our previous work [26], this carbon peak is attributed to the $\mathrm{CaCO}_{3}$ 
carbonates, the remaining carbon traces used during the UGS process reduction step. It can also be attributed to atmospheric $\mathrm{CO}_{2}$ absorbed or adsorbed. However, the SEM photos (Figure 8) showed the appearance of spherical particles in the spent catalyst compared to the fresh catalyst.

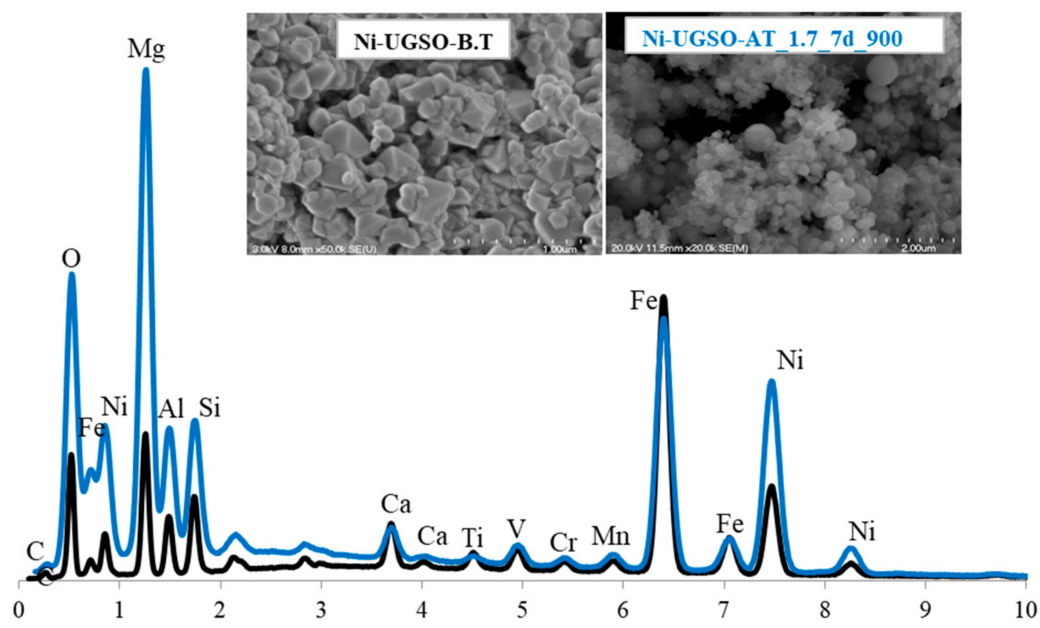

Figure 8. SEM and EDX of Ni-UGSO BT and Ni-UGSO AT (7 days, $\mathrm{H}_{2} \mathrm{O} / \mathrm{CH}_{4}=1.7,900{ }^{\circ} \mathrm{C}$ ).

The mapping analysis of the fresh catalyst (Figure 9) and used catalyst (Figure 10) showed that the former has a homogeneous morphology as well as a good dispersion of the active metal $(\mathrm{Ni})$ as well as those of the support $(\mathrm{Mg}, \mathrm{Al}$ and $\mathrm{Fe})$. After 7 days of reaction, the spent catalyst (Figure 10) showed the appearance of certain spherical particles consisting mainly of $\mathrm{Ni}$ and Fe. As described in the interpretation proposed during the DRM, these spherical particles were attributed to Ni-Fe alloys formed by reduction during the DRM.

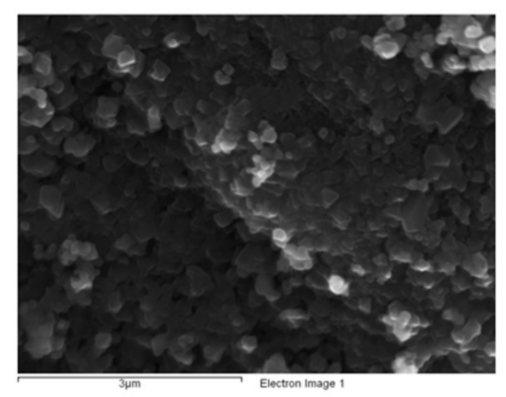

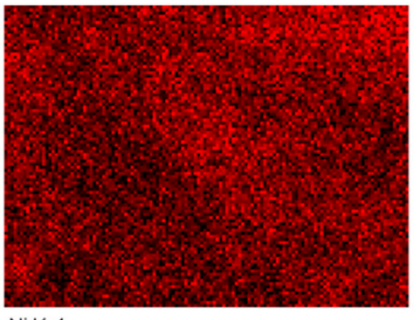
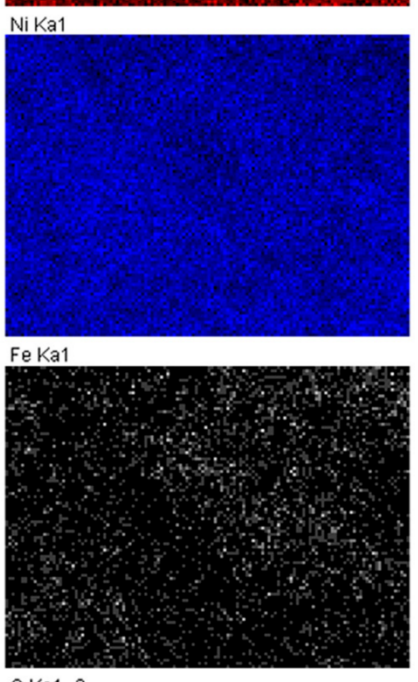

C Ka1_2
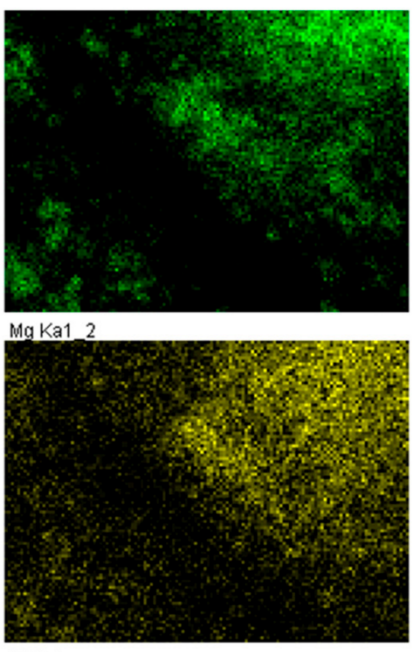

Al Ka1

Figure 9. Mapping analysis of Ni-UGSO BT. 

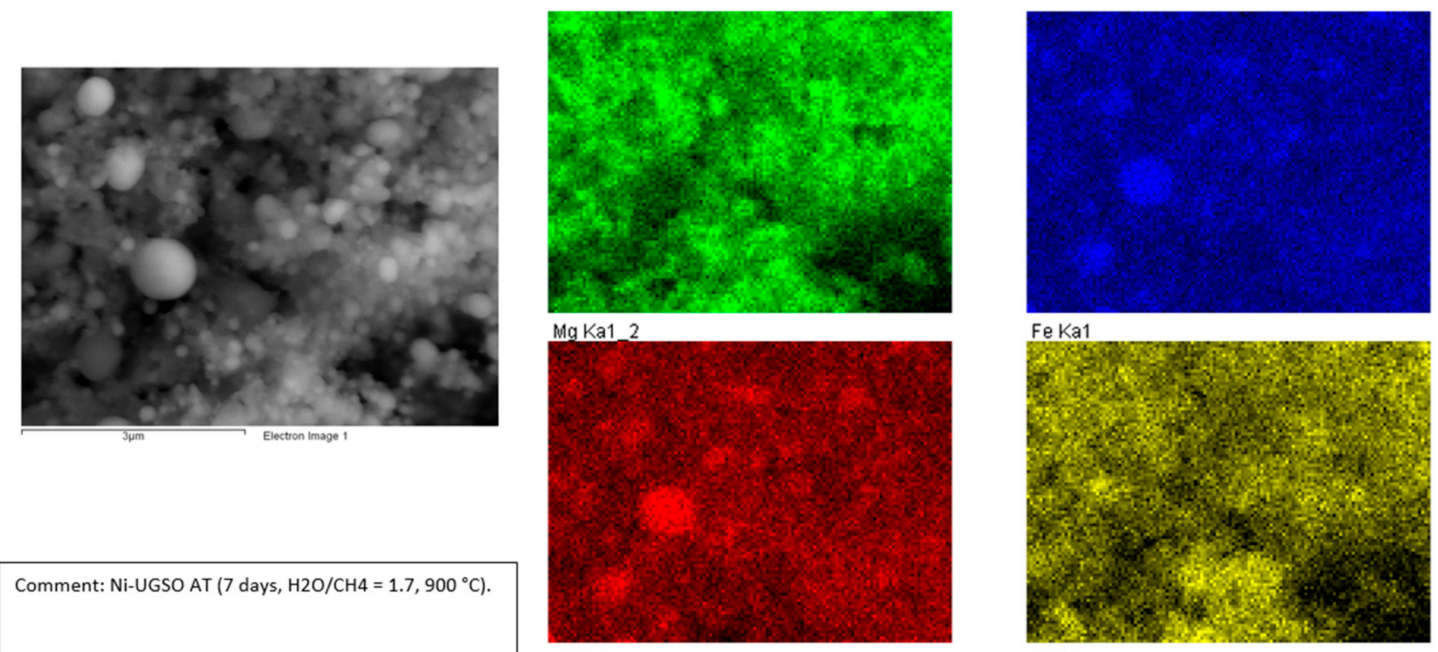

Comment: Ni-UGSO AT $\left(7\right.$ days, $\left.\mathrm{H} 2 \mathrm{O} / \mathrm{CH}_{4}=1.7,900^{\circ} \mathrm{C}\right)$.
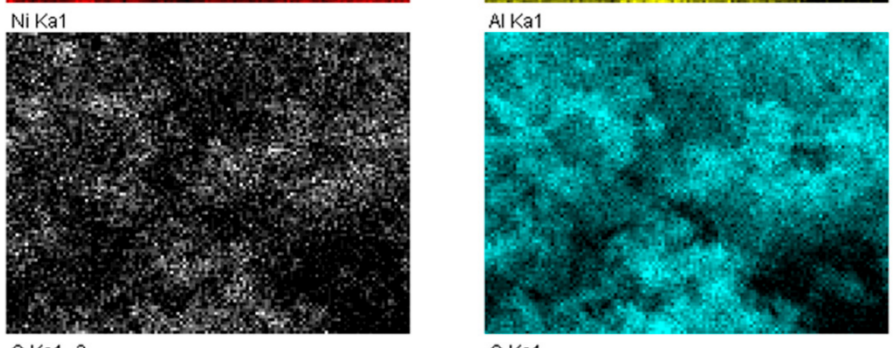

CKa1 2

OKa1

Figure 10. Mapping analysis of Ni-UGSO AT (7 days, $\left.\mathrm{H}_{2} \mathrm{O} / \mathrm{CH}_{4}=1.7,900{ }^{\circ} \mathrm{C}\right)$.

\subsection{Ni-UGSO Performance as a Catalyst for Mixed Methane Dry and Steam Reforming}

For this study, Ni-UGSO stability was validated in DRM using a $\mathrm{Q}_{\mathrm{CO} 2}=7.29 \mathrm{~mL} / \mathrm{min}$, $\mathrm{Q}_{\mathrm{CH} 4}=7.55 \mathrm{~mL} / \mathrm{min}$ and $\left.\mathrm{Q}_{\mathrm{H} 2 \mathrm{O}}=1.04 \mathrm{~mL} / \mathrm{min}\right)$ without $\mathrm{Ar}\left(\mathrm{H}_{2} \mathrm{O} / \mathrm{CH}_{4}=0.14, \mathrm{CO}_{2} / \mathrm{CH}_{4}\right.$ $=0.97$ and $\left.\mathrm{CH}_{4} /\left(\mathrm{CO}_{2}+\mathrm{H}_{2} \mathrm{O}\right)=0.91\right)$ for $74 \mathrm{~h}$. Three reaction temperature levels $\left(828{ }^{\circ} \mathrm{C}\right.$, $847^{\circ} \mathrm{C}$ and $896^{\circ} \mathrm{C}$ ) were used over these $74 \mathrm{~h}$ TOS.

$\mathrm{CH}_{4}$ conversion remained stable at each temperature level: $80 \%$ at $828^{\circ} \mathrm{C}(26 \mathrm{~h}), 85 \%$ at $847^{\circ} \mathrm{C}(24 \mathrm{~h})$ and $95 \%$ at $896^{\circ} \mathrm{C}(24 \mathrm{~h})$ (Figure 11).

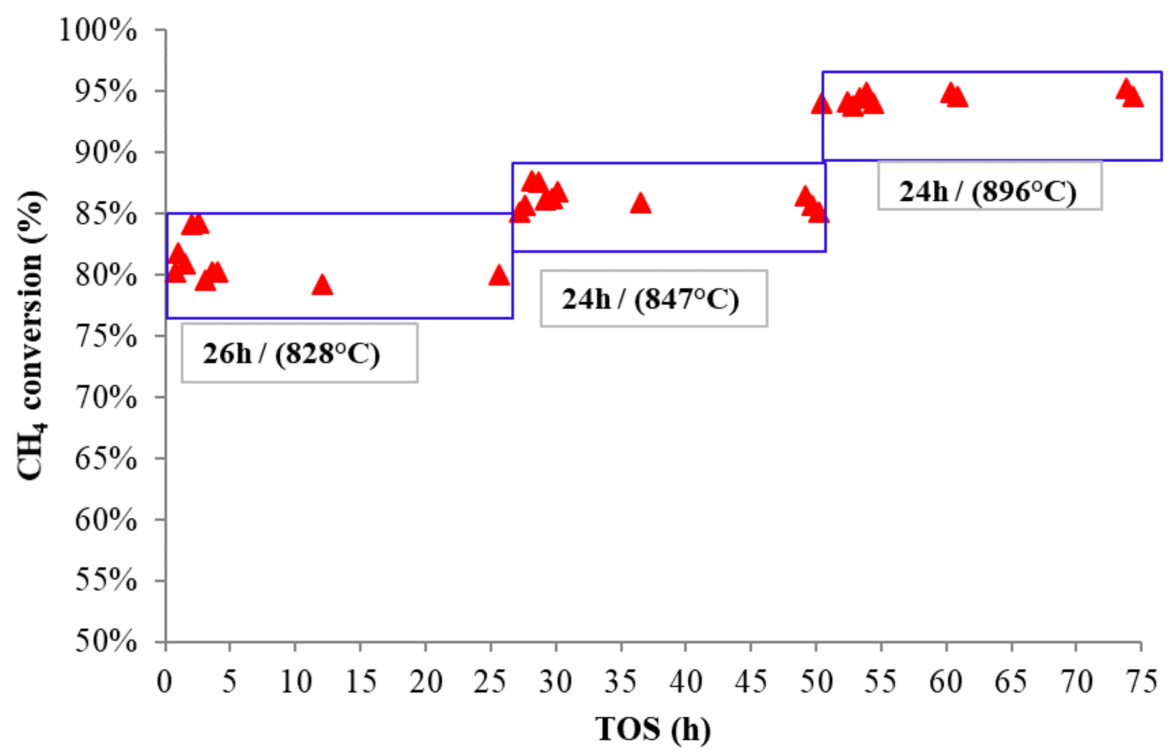

Figure 11. Catalytic performances of Ni-UGSO on mixed methane dry and steam reforming $\left(\mathrm{CO}_{2} / \mathrm{CH}_{4}=0.97\right.$ and $\left.\mathrm{H}_{2} \mathrm{O} / \mathrm{CH}_{4}=0.15\right)$. 
Referring to Figure S16 (Supplementary Materials), XRD of the Ni-UGSO catalyst used during $74 \mathrm{~h}$ of reaction showed that it had the same structure as that used for $4 \mathrm{~h}$ under the same conditions without any carbon deposition as illustrated by the SEM-EDX analyses (Figure S17, Supplementary Materials).

The results were the same order of magnitude as those obtained by Nakhaei et al. [34] in the mixed $\mathrm{CO}_{2}$ and steam reforming of methane. Experimental conditions were close to ours except for the temperature, which was slightly lower, and the GHSV, which was higher: $750{ }^{\circ} \mathrm{C}, \mathrm{CH}_{4} /\left(\mathrm{CO}_{2}+\mathrm{H}_{2} \mathrm{O}\right)=0.87, \mathrm{CH}_{4} / \mathrm{CO}_{2}=1$ and $\mathrm{CO}_{2} / \mathrm{H}_{2} \mathrm{O}=6.4$ and a GHSV $=20 \mathrm{~L} /(\mathrm{h} \cdot \mathrm{g})$. Different $\mathrm{Ni} / \mathrm{MgO} / \alpha-\mathrm{Al}_{2} \mathrm{O}_{3}$ catalysts were prepared with $\mathrm{Mg} 1 \mathrm{wt} \%$ and $\mathrm{Ni}$ 1 to $5 \mathrm{wt} \%$. Unlike our catalyst, which was used as it was produced, the Nakhaei et al. [34] catalyst underwent a pre-reduction. Results showed an increase of $\mathrm{CH}_{4}$ conversion from $54 \%$ to $74 \%$ upon increasing Ni loading from $1 \%$ to $5 \%$. The authors indicated that such performance is attributed to solid solution $\mathrm{NiO}-\mathrm{MgO}$ and that the reactions reach conversions and yields close to thermodynamic equilibrium.

By studying a mixed DRM and SRM, at a ratio $\left(\mathrm{CO}_{2}+\mathrm{H}_{2} \mathrm{O} / \mathrm{CH}_{4}\right)$ closer to 1 , at atmospheric pressure and at temperature greater than or equal to $800{ }^{\circ} \mathrm{C}$, Jabbour et al. [35] recently discovered that the use of $\mathrm{MgO}$ (or $\mathrm{CaO}$ ) basic promoters in $\mathrm{Ni} 5 \% \mathrm{Mg} 5 \% \mathrm{Al}_{2} \mathrm{O}_{3}$ or $\mathrm{Ni} 5 \% \mathrm{Ca} 5 \% \mathrm{Al}_{2} \mathrm{O}_{3}$ catalysts provided remarkable activity, stability and selectivity in syngas. Compared to unpromoted $\mathrm{Ni} 5 \%$ and $\mathrm{Ni} 10 \% \mathrm{Al}_{2} \mathrm{O}_{3}$, after $40 \mathrm{~h}$ of reaction, a significant reduction in deposited carbon was observed with improvement in the reactivity and purity of the synthesis gases obtained.

Similarly, Koo et al. [24] and Mehr et al. [36] led mixed steam and dry reforming of methane without and in the presence of $\mathrm{MgO}$-assisted, $\mathrm{Ni}$-impregnated on $\mathrm{Al}_{2} \mathrm{O}_{3}$ catalysts. The authors deduced that the addition of $\mathrm{MgO}$ had a positive effect on the eliminating carbon deposition and on reactivity and selectivity.

\section{Discussion}

The new Ni-UGSO catalyst, resulting from upgrading of a mining residue with a negative UGSO value, has demonstrated catalytic performance at least equal to that of the various homologous nickel-based catalysts described in the literature. Besides the catalytic performance in DRM, SRM and MRM occurring near thermodynamic equilibrium, no carbon deposit was detected, especially as it demonstrated good resistance to sulfides (low quantity).

All of these promising results are attributed to the different constituent elements of the UGSO mining residue despite not being catalytically active by themselves (Fe, $\mathrm{Mg}$, $\mathrm{Al}, \mathrm{Ca}, \mathrm{Mn}, \mathrm{V}, \mathrm{Ti}, \mathrm{Cr}, \mathrm{Na}, \mathrm{Si}, \mathrm{K}, \mathrm{P}, \mathrm{Zr}$ and $\mathrm{Zn}$ oxides and spinels). Indeed, the addition of $\mathrm{Ni}$ allows different interactions to be triggered synergistically between the components of UGSO and the active metal (Ni). It should be remembered that most of these elements, used as supports or promoters, have been the subject of several recommendations from studies aimed at reducing or eliminating the formation of coke on Ni-based catalysts. As demonstrated in our previous work [28], the reducing medium during the DRM causes a reduction of $\mathrm{NiFe}_{2} \mathrm{O}_{4}$ spinel compound into $\mathrm{FeO}, \mathrm{NiO}$ and metallic $\mathrm{Ni}$, Fe and some other alloys such as $\mathrm{FeNi}, \mathrm{FeNi}_{3}$ and $\mathrm{Fe}_{3} \mathrm{Ni}_{2}$. As described by Benrabaa et al. $[37,38]$, the fact that $\mathrm{Ni}$ is well dispersed in this alloy minimizes the formation of carbon deposit as much as possible.

Regarding the other elements constituting the residue used as a promoter, our interest has focused on magnesium oxide $(\mathrm{MgO})$ without neglecting the role of other elements whose effect is described in several articles in the literature.

In fact, several studies have demonstrated the positive effects of $\mathrm{MgO}$ as promoters with significant Lewis basicity and as an oxide easily forming a solid solution with $\mathrm{Ni}$ oxide ( $\mathrm{MgO}-\mathrm{NiO})$. On the one hand, the presence of basic Lewis sites $\left(\mathrm{O}^{2-}\right)$ [39] will reinforce the chemisorption of $\mathrm{CO}_{2}$ on these sites, and the adsorbed $\mathrm{CO}_{2}$ reacts with carbon. This reaction shifts the equilibrium of the reaction from Boudouard to $\mathrm{CO}\left(\mathrm{CO}_{2}+\mathrm{C} \rightarrow 2 \mathrm{CO}\right)$, promoting the coke elimination reaction, which considerably reduces the deposition of 
surface carbon [40]. On the other hand, Son et al. [41] reported that, with its oxygen storage capacity, $\mathrm{MgO}$ could remove carbon formed on the surface of a catalyst by its oxidation with liberated oxygen. The high nickel activity and carbon resistance are also attributed to the formation of a solid solution of $\mathrm{NiO}$ in $\mathrm{MgO}$.

Wang et al. [42] explain that the solid $\mathrm{NiO}-\mathrm{MgO}$ solution could have two main phases: A solid $\mathrm{NiO}-\mathrm{MgO}$ solution with a high Ni content in the outer layer and a solid $\mathrm{NiO}-\mathrm{MgO}$ solution with a very low $\mathrm{Ni}$ content in the mass. Thus, Ni particles can diffuse from the outer layer to the deeper layer to form a more stable structure at high temperatures, which prevents the sintering of nickel particles for high-temperature reactions. In addition, $\mathrm{Hu}$ and Ruckenstein [39] indicate that, due to the strong interaction between $\mathrm{NiO}$ and $\mathrm{MgO}$, the coalescence or aggregation of $\mathrm{Ni}$, which stimulates carbon formation, is inhibited. This strong interaction between $\mathrm{NiO}$ and $\mathrm{MgO}$ could also weaken the donor character of $\mathrm{Ni}$, thereby preventing disproportionation of CO. Bradford et al. [43] have shown that the $\mathrm{Ni} / \mathrm{MgO}$ catalyst is both active and stable during $44 \mathrm{~h}$ of dry reforming of $\mathrm{CH}_{4}$. Such performance and resistance to coke deposition were explained by the formation of a solid solution of $\mathrm{MgO}-\mathrm{NiO}$ due to the strong dissolution of $\mathrm{NiO}$ in $\mathrm{MgO}$. This partially reducible solution is reported to stabilize metal $\mathrm{Ni}$ and enhance resistance to carbon deposition. Likewise, the good catalytic performance of the $\mathrm{Ni} / \mathrm{MgAl}_{2} \mathrm{O}_{4}$ spinel, obtained by the addition of $\mathrm{MgO}$ to the $\mathrm{Ni} / \mathrm{Al}_{2} \mathrm{O}_{3}$ system, is attributed to a greater $\mathrm{CO}_{2}$ adsorption capacity due to the increase in the density of the basic Lewis sites of on the surface of the catalyst $[25,44]$.

\section{Materials and Methods}

\subsection{Materials}

\subsubsection{Constitutive Elements of the UGSO Residue}

Table 3 shows the constitutive elements of the UGSO residue obtained by ICP-MS analysis. $\mathrm{Fe}, \mathrm{Mg}$ and $\mathrm{Al}$ are the main elements.

\subsubsection{Particle Size Distribution}

The first raw UGSO (UGSO-L1) received from our industrial partner was milled in a mortar and sieved to collect the fraction corresponding to sizes below $53 \mu \mathrm{m}$ (smaller sieve); this fraction was chosen for the preparation of the catalytic formulations Table 4 shows the particle size distribution of this fraction of UGSO.

Table 4. Particle size distribution of UGSO-L1.

\begin{tabular}{cccccc}
\hline & d (0.1) & d (0.2) & d (0.5) & d (0.8) & d (0.9) \\
\hline $\operatorname{UGSO}(\mu \mathrm{m})$ & 1.75 & 6.51 & 25.85 & 48.07 & 61.42 \\
\hline
\end{tabular}

\subsection{Ni-UGSO Preparation via Improved Solid-State Reaction}

Ni-UGSO was prepared following the improved solid-state reaction developed in a previous work [26-28]. To study the effect of the content of $\mathrm{Ni}, 3,6,9,10$ and $13 \mathrm{wt} \%$ were added. Table 5 shows particle size distribution and Ni-UGSO (13 wt \%) compared to UGSO.

Table 5. Particle size distribution of Ni-UGSO (13 wt $\%$ ).

\begin{tabular}{cccccc}
\hline & d (0.1) & d (0.2) & d (0.5) & d (0.8) & d (0.9) \\
\hline Ni-UGSO $(\mu \mathrm{m})$ & 1.24 & 3.71 & 20.34 & 46.83 & 56.97 \\
\hline
\end{tabular}

\subsection{Catalysts Characterization}

Our previous work [26] describes various characterization techniques used to analyze the new Ni-UGSO catalyst, such as X-ray diffraction (XRD), scanning electron microscopyenergy dispersive X-ray (SEM-EDX), temperature-programmed reduction (TPR), X-ray 
photoemission spectrometry (XPS), thermogravimetric analysis (TGA) coupled with mass spectroscopy (MS) and BET specific surface.

\subsection{Use of Ni-UGSO as a Catalyst}

The produced Ni-UGSO was used as a catalyst for DRM, SRM and mixed methane reforming (MRM).

The experiments were conducted under the same conditions as those described in a previous work [27] at atmospheric pressure in a differential fixed-bed catalytic reactor (Figure 12) using 0.3-0.5 g of Ni-UGSO. Total flow rate and space velocity were $15 \mathrm{~mL} / \mathrm{min}$ and $3000 \mathrm{~mL} /$ (h.gcat) respectively.

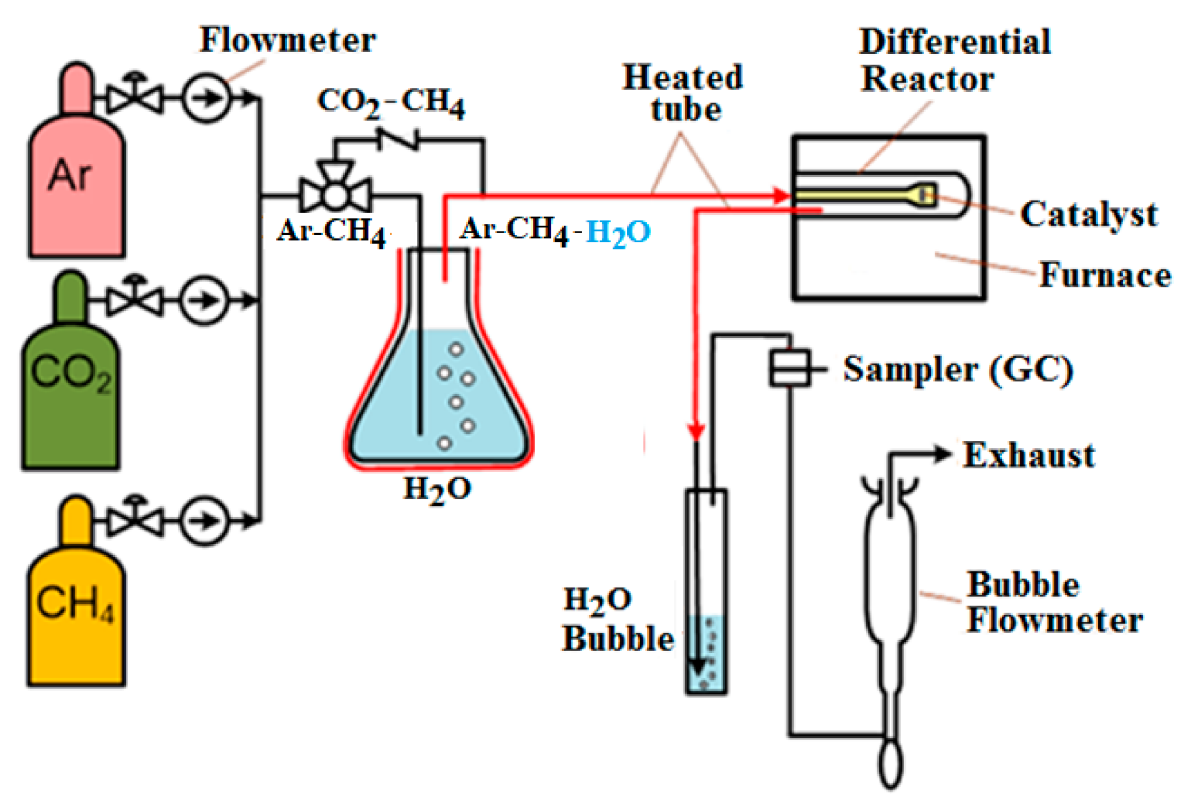

Figure 12. Schematic of DRM, SMR and mixed reforming microreactor.

Gases were fed from commercial gas cylinders (supplied by Praxair, Sherbrooke, Québec, Canada): $\mathrm{CH}_{4}(99 \%), \mathrm{CO}_{2}(99 \%)$ and $\mathrm{Ar}(99 \%)$. Flow rates of $\mathrm{CO}_{2}$ and $\mathrm{CH}_{4}$ were adjusted by the AALBORG-type mass flow controller (Model GFC17) (supplied by AALBORG, Orangeburg, NY, USA). Flow rates of the reactants and the reaction products were also measured by a bubble meter. In the case of SRM, a mixture of argon and methane is saturated in the bubbler, and the desired amount of water is regulated using the water temperature control. At saturation at $73{ }^{\circ} \mathrm{C}$, the partial pressure of water vapour is $354.45 \mathrm{hPa}$. For $32 \%$ of $\mathrm{CH}_{4}$ in $\mathrm{Ar}$, the $\mathrm{CH}_{4}$ partial pressure is $212.97 \mathrm{hPa}$ corresponding to a $\mathrm{H}_{2} \mathrm{O} / \mathrm{CH}_{4}$ ratio $=1.7$. The effluents were analyzed using a gas chromatograph (Varian CP-3800) (supplied by Varian, Inc, Walnut Creek, CA, USA) equipped with Hayesep and Molsieve columns and with thermal conductivity (TCD) and flame ionization (FID) detectors. Helium and nitrogen were used as carrier gases, and hydrogen and air were used for the detector flame. The flow rates of gases are: $18.8 \mathrm{~mL} / \mathrm{min}(\mathrm{He}), 21.2 \mathrm{~mL} / \mathrm{min}$ $\left(\mathrm{N}_{2}\right), 30 \mathrm{~mL} / \mathrm{min}\left(\mathrm{H}_{2}\right)$ and $300 \mathrm{~mL} / \mathrm{min}$ (air). The columns and the detector were heated to $175{ }^{\circ} \mathrm{C}$ at a rate of $20{ }^{\circ} \mathrm{C} / \mathrm{min} . \mathrm{H}_{2}, \mathrm{CO}, \mathrm{CH}_{4}$, and $\mathrm{CO}_{2}$ are the main gases detected. Calibration was performed using gas mixture standards at different concentrations. The concentrations of reactants were added to the experimental conditions of each type of test. 


\subsection{Reaction Metrics}

Conversion of $\mathrm{CH}_{4}$ was calculated by Equation (1). $\mathrm{H}_{2}$ and $\mathrm{CO}$ yields as defined by Equations (2) and (3) respectively:

$$
\begin{gathered}
X_{i}(\%)=\frac{F_{i, \text { in }}-F_{i, \text { out }}}{F_{i, \text { in }}} \times 100 \\
Y_{\mathrm{H}_{2}}(\%)=\frac{F_{\mathrm{H}_{2}}}{2 \times F_{\mathrm{CH}_{4, \text { in }}}} \times 100 \\
Y_{\mathrm{CO}}(\%)=\frac{F_{\mathrm{CO}}}{F_{\mathrm{CH}_{4, \text { in }}}+F_{\mathrm{CO}_{2, \text { in }}}} \times 100
\end{gathered}
$$

where $F_{i, \text { in }}$ or $F_{i, \text { out }}$ is the flow rate of each component in the feed or effluent.

Concerning the experimental errors of the various reforming results, we proceeded, for brevity and figure-readability reasons, to the calculation of the standard deviations of the material balances (atomic: $\mathrm{C}, \mathrm{H}, \mathrm{O})$ instead of error bars: $\mathrm{C}(1.4 \%), \mathrm{O}(3.9 \%)$ and $\mathrm{H}$ $(6.3 \%)$.

As shown in Table 6, the standard deviation was calculated from the average of the averages of each study below (Table 7):

- influence of the active phase content on the catalytic activity;

- influence of catalyst calcination time;

- representativeness of UGSO mining residue lots;

- $\quad$ Ni-UGSO sulfur poisoning resistance;

- $\quad$ Ni-UGSO performance as a catalyst for steam methane reforming (SRM);

- $\quad$ Ni-UGSO performance as a catalyst for mixed methane dry and steam reforming (MRM).

Table 6. Error mean and standard deviation.

\begin{tabular}{cccc}
\hline & $\mathbf{C}$ & $\mathbf{O}$ & $\mathbf{H}$ \\
\hline Error mean & $2.59 \%$ & $4.47 \%$ & $3.99 \%$ \\
Standard deviation & $1.35 \%$ & $3.93 \%$ & $6.28 \%$ \\
\hline
\end{tabular}

The following table shows the error mean and standard deviation.

Table 7. Average errors on atomic carbon, hydrogen and oxygen for of each study.

\begin{tabular}{cccc}
\hline & $\mathbf{C}$ & $\mathbf{O}$ & $\mathbf{H}$ \\
\hline Effect of Ni content & $3.58 \%$ & $8.03 \%$ & $8.81 \%$ \\
Effect of calcination time & $2.55 \%$ & $3.54 \%$ & $7.87 \%$ \\
Ni-UGSO sulfur poisoning resistance & $2.54 \%$ & $4.93 \%$ & $-7.84 \%$ \\
Representativeness of UGSO mining residue lots & $-0.18 \%$ & $-1.35 \%$ & $9.31 \%$ \\
Steam methane reforming (SMR) & $4.07 \%$ & $10.37 \%$ & $6.63 \%$ \\
Mixed methane dry and steam reforming & $2.97 \%$ & $1.31 \%$ & $-0.84 \%$ \\
\hline
\end{tabular}

This means that our confidence interval for carbon was $2.59 \pm 1.35$.

\section{Conclusions}

In this work, UGSO mining waste was doped with Ni using a recently published improved solid-state reaction protocol; the resulting spinelized structure proved to be a robust and highly active Ni-UGSO reforming catalyst. DRM, SRM, MRM and sulfur poisoning resistance were chosen to test the catalytic performance and robustness of this new catalyst. The DRM and SRM reactions demonstrated an excellent hydrocarbon conversion and hydrogen yield and the $\mathrm{H}_{2} / \mathrm{CO}$ ratios obtained in the product were close to 1 (for 
DRM) and close to 3 (for SRM); these ratios are nearly those expected for thermodynamic equilibrium in the experimental conditions tested.

As mentioned before, the constituent elements of the UGSO had a positive effect on the performance of the catalyst, allowing a good dispersion and interaction of $\mathrm{Ni}$ in the UGSO. As in previously published works in this area, our results also show that, in addition to the effect of certain $\mathrm{Ni}_{x} \mathrm{Fe}_{\mathrm{y}}$ alloys, the $\mathrm{Ni}$ inside the spinel structure leads to a high stability and a high dispersion of the particles of the active metal, limiting the growth of the Ni particles preventing the formation of carbon while maintaining a high catalytic activity. Likewise, the basic character of components like $\mathrm{MgO}$ acts as catalyst promoters by inhibiting the carbon formation on the catalyst surface and stimulating the solid carbon gasification. Furthermore, the protection of the metallic Ni (which is formed during reduction) by the solid solution $\mathrm{Ni} / \mathrm{NiO} / \mathrm{MgO}$ could explain the activity and the stability of the catalyst.

In conclusion, of these four types of investigation in this work, $\mathrm{CH}_{4}$ conversion in SRM remained stable at around $98 \%$ during the $168 \mathrm{~h}$ TOS of reaction under 1 bar at $900{ }^{\circ} \mathrm{C}$ at a molar $\mathrm{H}_{2} \mathrm{O} / \mathrm{CH}_{4}=1.7$. Likewise, in DRM, $\mathrm{CH}_{4}$ conversion rapidly reaches $92 \%$ and remains stable over $168 \mathrm{~h}$ TOS under 1 bar at $810^{\circ} \mathrm{C}$ and at molar $\mathrm{CO}_{2} / \mathrm{CH}_{4}=1.2$. For mixed $\mathrm{CH}_{4}$ reforming using a molar ratio of $\mathrm{H}_{2} \mathrm{O} / \mathrm{CH}_{4}=0.15$ and $\mathrm{CO}_{2} / \mathrm{CH}_{4}=0.97$ for $74 \mathrm{~h}$ under 1 bar and three reaction temperature levels $\left(828^{\circ} \mathrm{C}, 847^{\circ} \mathrm{C}\right.$ and $\left.896^{\circ} \mathrm{C}\right), \mathrm{CH}_{4}$ conversion remains stable at each temperature level: $80 \%$ at $828^{\circ} \mathrm{C}(26 \mathrm{~h}), 85 \%$ at $847^{\circ} \mathrm{C}$ $(24 \mathrm{~h})$ and $95 \%$ at $896{ }^{\circ} \mathrm{C}(24 \mathrm{~h})$. Five levels of Ni mass contents $(3 \%, 6 \%, 9 \%, 10 \%$ and $13 \%$ ) in the Ni-UGSO formulation have been compared at $840{ }^{\circ} \mathrm{C}$ and a molar $\mathrm{CO}_{2} / \mathrm{CH}_{4}$ of 1.25 . The best performances was observed with the $10 \% w / w$ Ni catalyst. Statistically similar performance was obtained with the $13 \% w / w$ Ni catalyst. The catalysts Ni-UGSO calcined at $900{ }^{\circ} \mathrm{C}$ for $3 \mathrm{~h}$ and $12 \mathrm{~h}$ give the same catalytic performances at $840{ }^{\circ} \mathrm{C}$ with a $\mathrm{CO}_{2} / \mathrm{CH}_{4}=1.2$. Even though the composition of the two batches of UGSO used to produce the Ni-UGSO catalytic formulation are slightly different, both Ni-UGSO catalysts demonstrated equivalent performance during DRM at $840{ }^{\circ} \mathrm{C}$ and molar $\mathrm{CO}_{2} / \mathrm{CH}_{4}=1.2$. The catalyst showed no deactivation up to $5.5 \mathrm{ppm}$ of $\mathrm{H}_{2} \mathrm{~S}$. A slight deactivation (3\%) was observed at $12 \mathrm{ppm}$ and remained stable throughout the $1 \mathrm{~h}$ exposure of the catalyst to $\mathrm{H}_{2} \mathrm{~S}$.

Supplementary Materials: The following are available online at https:/ /www.mdpi.com/article/ 10.3390/catal11070771/s1. Figure S1: Evolution of free enthalpies $(\Delta \mathrm{G}(\mathrm{T}))$ of DRM and SRM reactions as a function of temperature, Figure $\mathrm{S} 2: \mathrm{CH}_{4}$ and $\mathrm{CO}_{2}$ conversions and composition of gas mixtures and graphitic carbon at thermodynamic equilibrium for the DRM reaction, Figure S3: Thermodynamic equilibrium $\mathrm{H}_{2} / \mathrm{CO}$ ratio for the DRM reaction, Figure $\mathrm{S} 4: \mathrm{CH}_{4}$ and $\mathrm{CO}_{2}$ conversions and composition of gas mixtures and graphitic carbon at thermodynamic equilibrium for the SRM reaction, Figure S5: Thermodynamic equilibrium $\mathrm{H}_{2} / \mathrm{CO}$ ratio for the SRM reaction, Figure S6: Effect of Ni content: evolution of $\mathrm{CO}_{2}$ conversion as a function of time at $842{ }^{\circ} \mathrm{C}, \mathrm{CO}_{2} / \mathrm{CH}_{4}=1.25$, Figure S7: Effect of Ni content: evolution of $\mathrm{H}_{2}$ yield as a function of time at $842{ }^{\circ} \mathrm{C}, \mathrm{CO}_{2} / \mathrm{CH}_{4}=1.25$, Figure S8: Effect of Ni content: evolution of $\mathrm{H}_{2} / \mathrm{CO}$ ratio as a function of time at $842{ }^{\circ} \mathrm{C}, \mathrm{CO}_{2} / \mathrm{CH}_{4}=$ 1.25, Figure S9: Mapping study as function of Ni-loading, Figure S10: XRD catalysts calcined at 900 ${ }^{\circ} \mathrm{C}$ for $1 \mathrm{~h}, 3 \mathrm{~h}$ and $12 \mathrm{~h}$, Figure S11: XRD of the two lots of UGSO compared to that of the UGSO L1 calcined at $900{ }^{\circ} \mathrm{C} / 12 \mathrm{~h}$, Figure S12: XRD of the of UGSO-L2 compared to that of the UGSO-L3 calcined at $900{ }^{\circ} \mathrm{C} / 12 \mathrm{~h}$, Figure S13: XRD of Ni-UGSO catalysts from 2 lots calcined at $900{ }^{\circ} \mathrm{C}$ for $1 \mathrm{~h}$, Figure S14: XRD of spent Ni-UGSO catalysts without and with $\mathrm{H}_{2} \mathrm{~S}$, Figure S15: XRD of Ni-UGSO used for 7 days at the SRM $\left(\mathrm{H}_{2} \mathrm{O} / \mathrm{CH}_{4}=1.7,900^{\circ} \mathrm{C}\right)$ compared to the fresh catalyst Ni-UGSO BT, Figure S16: XRD of used catalyst Ni-UGSO AT $(4 \mathrm{~h} \& 74 \mathrm{~h})\left(\mathrm{CO}_{2} / \mathrm{CH}_{4}=0.97\right.$ and $\left.\mathrm{H}_{2} \mathrm{O} / \mathrm{CH}_{4}=0.15\right)$, Figure S17: SEM-EDX of used catalyst Ni-UGSO AT $(4 \mathrm{~h} \& 74 \mathrm{~h})\left(\mathrm{CO}_{2} / \mathrm{CH}_{4}=0.97\right.$ and $\mathrm{H}_{2} \mathrm{O} / \mathrm{CH}_{4}=$ $0.15)$.

Author Contributions: M.C., co-inventor with N.A. of the catalytic formulations tested has contributed in choosing the catalytic formulations, the experimental protocols, technically in adopting the most appropriate experimental protocols and in the scientific interpretation of the results. N.A., the corresponding author, is the scientific and technical director of the R\&D program. He has con- 
tributed to choosing the experimental protocols and the catalytic formulations. He has also worked with the first author in reviewing the first draft and finalizing the manuscript. All authors have read and agreed to the published version of the manuscript.

Funding: This research was funded by FRQNT (Fonds de recherche du Quebec_Nature and technologies), grant number: 2017-MI-202929.

Data Availability Statement: We would like to share these data; however, there are confidentiality issues; these data are used for the advancement of our current work in collaboration with our industrial partners.

Acknowledgments: We would like to thank FRQNT (Fonds de recherche du Quebec_Nature and technologies) for the financial support of this project. Special thanks to Guillaume Hudon and Yves Pepin of Rio Tinto Iron and Titanium (RTIT), for both funding and for providing the metallurgical residue and their technical support. We thank also Sonia Blais, Stephane Gutierrez, Carl Saint-Louis and Charles Bertrand of PRAM (Plateforme de recherche et d'analyse des matériaux) at Université de Sherbrooke for their technical assistance in instrumental analyses.

Conflicts of Interest: The authors declare no conflict of interest.

\section{References}

1. Rostrup-Nielsen, J.R.; Sehested, J.; Nørskov, J.K. Hydrogen and synthesis gas by steam- and $\mathrm{CO}_{2}$ reforming. Adv. Catal. 2002, 47, 65-139. [CrossRef]

2. Levent, M.; Gunn, D.J.; Ali El-Bousiffi, M. Production of hydrogen-rich gases from steam reforming of methane in an automatic catalytic microreactor. Int. J. Hydrogen Energy 2003, 28, 945-959. [CrossRef]

3. Iulianelli, A.; Manzolini, G.; De Falco, M.; Campanari, S.; Longo, T.; Liguori, S.; Basile, A. $\mathrm{H}_{2}$ production by low pressure methane steam reforming in a Pd-Ag membrane reactor over a Ni-based catalyst: Experimental and modeling. Int. J. Hydrogen Energy 2010, 35, 11514-11524. [CrossRef]

4. Tullo, A.H. Dry reforming puts $\mathrm{CO}_{2}$ to works. Chemical $\mathcal{E}$ Engineering News, 25 April 2016, p. 17. Available online: https: // cen.acs.org/articles/94/i17/Dry-reforming-puts-CO2-work.html?ref=search_results (accessed on 24 June 2021).

5. $\mathrm{Xu}, \mathrm{L} . ;$ Song, H.; Chou, L. Carbon dioxide reforming of methane over ordered mesoporous $\mathrm{NiO}-\mathrm{MgO}^{-} \mathrm{Al}_{2} \mathrm{O}_{3}$ composite oxides. Appl. Catal. B Environ. 2011, 108, 177-190. [CrossRef]

6. Seo, H.O.; Sim, J.K.; Kim, K.D.; Kim, Y.D.; Lim, D.C.; Kim, S.H. Carbon dioxide reforming of methane to synthesis gas over a $\mathrm{TiO}_{2}-\mathrm{Ni}$ inverse catalyst. Appl. Catal. A Gen. 2013, 451, 43-49. [CrossRef]

7. Ondrey, G. Making Co-Rich Syngas While Avoiding Carbon Formation. Available online: https://www.chemengonline.com (accessed on 13 November 2019).

8. Mark, M.F.; Mark, F.; Maier, W.F. Reactions kinetics of the $\mathrm{CO}_{2}$ reforming of methane. Chem. Eng. Technol. 1997, 20, 361-370. [CrossRef]

9. Tsang, S.C.; Claridge, J.B.; Green, M.L. Recent advances in the conversion of methane to synthesis gas. Catal. Today 1995, 23, 3-15. [CrossRef]

10. Corthals, S.; Van Nederkassel, J.; Geboers, J.; De Winne, H.; Van Noyen, J.; Moens, B.; Sels, B.; Jacobs, P. Influence of composition of $\mathrm{MgAl}_{2} \mathrm{O}_{4}$ supported $\mathrm{NiCeO}_{2} \mathrm{ZrO}_{2}$ catalysts on coke formation and catalyst stability for dry reforming of methane. Catal. Today 2008, 138, 28-32. [CrossRef]

11. Menegazzo, F.; Signoretto, M.; Pinna, F.; Cauton, P.; Pernicone, N. Optimization of bimetallic dry reforming catalysts by temperature programmed reaction. Appl. Catal. A Gen. 2012, 439-440, 80-87. [CrossRef]

12. De Liobet, S.; Pinilla, J.L.; Moliner, R.; Suelves, I. Relationship between carbon morphology and catalyst deactivation in the catalytic decomposition of biogas using Ni, Co and Fe based catalysts. Fuel 2015, 139, 71-78. [CrossRef]

13. Nagaoka, K.; Seshan, K.; Lercher, J.A.; Aika, K. Activation mechanism of methane derived coke $\left(\mathrm{CH}_{\mathrm{x}}\right)$ by $\mathrm{CO}_{2}$ during dry reforming of methane comparison for Pt $/ \mathrm{Al}_{2} \mathrm{O}_{3}$ and $\mathrm{Pt} / \mathrm{ZrO}_{2}$. Catal. Lett. 2000, 70, 109-116. [CrossRef]

14. Provendier, H.; Petit, C.; Estournès, C.; Libs, S.; Kiennemann, A. Stabilisation of active nickel catalysts in partial oxidation of methane to synthesis gas by iron addition. Appl. Catal. A Gen. 1999, 180, 163-173. [CrossRef]

15. Salhi, N.; Boulahouache, A.; Petit, C.; Kiennemann, A.; Rabia, C. Steam reforming of methane to syngas over $\mathrm{NiAl}_{2} \mathrm{O}_{4} \mathrm{spinel}$ catalysts. Int. J. Hydrogen Energy 2011, 36, 11433-11439. [CrossRef]

16. Abatzoglou, N.; Fauteux-Lefebvre, C.; Blanchard, J.; Gitzhofer, F. Steam Reforming of Hydrocarbons over a Ni-Alumina Spinel Catalyst. J. Power Sources 2010, 195, 3275-3283.

17. Fauteux-Lefebvre, C.; Abatzoglou, N.; Braidy, N.; Achouri, I.E. Diesel steam reforming with a nickel-alumina spinel catalyst for solid oxide fuel cell application. J. Power Sources 2011, 196, 7673-7680. [CrossRef]

18. Achouri, I.E.; Abatzoglou, N.; Fauteux-Lefebvre, C.; Braidy, N. Diesel steam reforming: Comparison of two nickel aluminate catalysts prepared by wet-impregnation and co-precipitation. Catal. Today 2013, 207, 13-20. [CrossRef]

19. Wang, S.; Lu, G.Q. Effects of promoters on catalytic activity and carbon deposition of $\mathrm{Ni} / \gamma-\mathrm{Al}_{2} \mathrm{O}_{3}$ catalysts in $\mathrm{CO}_{2}$ reforming of $\mathrm{CH}_{4}$. J. Chem. Technol. Biot. 2000, 75, 589-595. [CrossRef] 
20. Sutthiumporn, K.; Kawi, S. Promotional effect of alkaline earth over $\mathrm{Ni}_{-} \mathrm{La}_{2} \mathrm{O}_{3}$ catalyst for $\mathrm{CO}_{2}$ reforming of $\mathrm{CH}_{4}$ : Role of surface oxygen species on $\mathrm{H}_{2}$ production and carbon suppression. Int. J. Hydrogen Energy 2011, 36, 14435-14446. [CrossRef]

21. Al-Fatesh, A.S.; Fakeeha, A.H.; Abasaeed, A.E. Effects of selected promoters on $\mathrm{Ni} / \gamma-\mathrm{Al}_{2} \mathrm{O}_{3}$ Catalyst performance in methane dry reforming. Chin. J. Catal. 2011, 32, 1604-1609. [CrossRef]

22. Luna, A.E.; Iriarte, M.E. Carbon dioxide reforming of methane over a metal modified $\mathrm{Ni}-\mathrm{Al}_{2} \mathrm{O}_{3}$ catalyst. Appl. Catal. A Gen. 2008, 343, 10-15. [CrossRef]

23. Siahvashi, A.; Adesina, A.A. Synthesis gas production via propane dry $\left(\mathrm{CO}_{2}\right)$ reforming: Influence of potassium promotion on bimetallic Mo-Ni/ $\mathrm{Al}_{2} \mathrm{O}_{3}$. Catal. Today 2013, 214, 30-41. [CrossRef]

24. Koo, K.Y.; Roh, H.S.; Seo, Y.T.; Seo, D.J.; Yoon, W.L.; Park, S.B. Coke study on MgO-promoted Ni/ $\mathrm{Al}_{2} \mathrm{O}_{3}$ catalyst in combined $\mathrm{H}_{2} \mathrm{O}$ and $\mathrm{CO}_{2}$ reforming of methane for gas to liquid (GTL) process. Appl. Catal. A Gen. 2008, 340, 183-190. [CrossRef]

25. Ranjbar, A.; Rezaei, M. Preparation of nickel catalysts supported on $\mathrm{CaO} \cdot 2 \mathrm{Al}_{2} \mathrm{O}_{3}$ for methane reforming with carbon dioxide. Int. J. Hydrogen Energy 2012, 37, 6356-6362. [CrossRef]

26. Chamoumi, M.; Abatzoglou, N.; Blanchard, J.; Iliuta, M.C.; Larachi, F. Dry reforming of methane with a new catalyst derived from a negative value mining residue spinellized with nickel. Catal. Today 2017, 291, 86-98. [CrossRef]

27. Abatzoglou, N.; Chamoumi, M. Process for Producing Catalysts from Metallurgical Tailings and Catalysts Produced Therefrom. U.S. Patent WO/2017/011906A1, 26 January 2017.

28. Chamoumi, M.; Abatzoglou, N. $\mathrm{NiFe}_{2} \mathrm{O}_{4}$ production from $\alpha-\mathrm{Fe}_{2} \mathrm{O}_{3}$ via an improved solid state reaction and its use as a dry reforming catalyst. Can. J. Chem. Eng. 2016, 94, 1801-1808. [CrossRef]

29. Requies, J.; Cabrero, M.A.; Barrio, V.L.; Guemez, M.B.; Cambra, J.F.; Arias, P.L.; Perez-Alonso, F.J.; Ojeda, M.; Pena, M.A.; Fierro, J.L.G. Partial oxidation of methane to syngas over $\mathrm{Ni} / \mathrm{MgO}$ and $\mathrm{Ni} / \mathrm{La}_{2} \mathrm{O}_{3}$ catalysts. Appl. Catal. A Gen. 2005, $289,214-223$. [CrossRef]

30. Chamoumi, M. Nouvelle Génération de Catalyseurs Supportés par Valorisation d'un Résidu d'Enrichissement (Procédé UGS) d'une Scorie de $\mathrm{TiO}_{2}$ : Le Catalyseur Ni-UGSO Appliqué au Reformage de Méthane [New Generation of Catalysts Supported by Upgrading an Enrichment Residue (UGS Process) of $\mathrm{TiO}_{2}$ Slag: Ni-UGSO Catalyst Applied to Methane Reforming]. Ph.D. Thesis, Université de Sherbrooke, Sherbrooke, QC, Canada, 2017.

31. Blondel Dega, F.; Abatzoglou, N. $\mathrm{H}_{2} \mathrm{~S}$ poisoning and pegeneration of a nickel spinellized catalyst prepared from waste metallurgical residues, during dry autothermal methane reforming. Catal. Lett. 2019, 149, 1730-1742. [CrossRef]

32. Rostrup-Nielsen, J.R. Catalytic steam reforming. In Catalysis: Science and Technology; Anderson, J.R., Boudart, M., Eds.; SpringerVerlag: Berlin/Heidelberg, Germany; New York, NY, USA; Tokyo, Japan, 1984; pp. 1-117.

33. Bimbela, F.; Chen, D.; Ruiz, J.; Garcia, L.; Arauzo, J. Ni/Al coprecipitated catalysts modified with magnesium and copper for the catalytic steam reforming of model compounds from biomass pyrolysis liquids. Appl. Catal. B Environ. 2012, 119-120, 1-12. [CrossRef]

34. Nakhaei Pour, A.; Mousavi, M. Combined reforming of methane by carbon dioxide and water: Particle size effect of Ni-Mg nanoparticles. Int. J. Hydrogen Energy 2015, 40, 12985-12992. [CrossRef]

35. Jabbour, K.; Massiani, P.; Davidson, A.; Casale, S.; El Hassan, N. Ordered mesoporous “one-pot" synthesized $\mathrm{Ni}^{-\mathrm{Mg}}(\mathrm{Ca})-\mathrm{Al}_{2} \mathrm{O}_{3}$ as effective and remarkably stable catalysts for combined steam and dry reforming of methane (CSDRM). Appl. Catal. B Environ. 2017, 201, 527-542. [CrossRef]

36. Mehr, Y.; Jozani, K.J.; Pour, A.N.; Zamani, Y. Influence of $\mathrm{MgO}$ in the $\mathrm{CO}_{2}$-Steam reforming of methane to syngas by $\mathrm{NiO} / \mathrm{MgO} / \alpha-\mathrm{Al}_{2} \mathrm{O}_{3}$ catalyst. React. Kinet. Catal. Lett. 2002, 75, 267-273. [CrossRef]

37. Benrabaa, R.; Boukhlouf, H.; Lofberg, A.; Rubbens, A.; Vannier, R.N.; Bordes-Richard, E.; Barama, A. Nickel ferrite spinel as catalyst precursor in the dry reforming of methane: Synthesis, characterization and catalytic properties. J. Nat. Gas. Chem. 2012, 21, 595-604. [CrossRef]

38. Benrabaa, R.; Lofberg, A.; Rubbens, A.; Bordes-Richard, E.; Vannier, R.N.; Barama, A. Structure, reactivity and catalytic properties of nanoparticles of nickel ferrite in the dry reforming of methane. Catal. Today 2013, 203, 188-195. [CrossRef]

39. $\mathrm{Hu}$, Y.H.; Ruckenstein, E. Characterization of a highly effective $\mathrm{NiO} / \mathrm{MgO}$ solid solution catalyst in $\mathrm{CO}_{2}$ reforming of $\mathrm{CH}_{4}$. Catal Lett. 1997, 43, 71-77. [CrossRef]

40. $\mathrm{Xu}$, L.; Song, $\mathrm{H}$; Chou, L. Ordered mesoporous $\mathrm{MgO}-\mathrm{Al}_{2} \mathrm{O}_{3}$ composite oxides supported Ni based catalysts for $\mathrm{CO}_{2}$ reforming of $\mathrm{CH}_{4}$ : Effects of basic modifier and mesopore structure. Int. J. Hydrogen Energy 2013, 38, 7307-7325. [CrossRef]

41. Son, I.H.; Lee, S.J.; Roh, H.S. Hydrogen production from carbon dioxide reforming of methane over highly active and stable $\mathrm{MgO}$ promoted $\mathrm{Co}-\mathrm{Ni} / \alpha-\mathrm{Al}_{2} \mathrm{O}_{3}$ catalyst. Int. J. Hydrogen Energy 2014, 39, 3762-3770. [CrossRef]

42. Wang, T.; Chang, J.; Cui, X.; Zhang, Q.; Fu, Y. Reforming of raw fuel gas from biomass gasification to syngas over highly stable nickel-magnesium solid solution catalysts. Fuel Process. Technol. 2006, 87, 421-428. [CrossRef]

43. Bradford, M.; Vannice, M. $\mathrm{CO}_{2}$ reforming of $\mathrm{CH}_{4}$. Catal. Rev. 1991, 41, 1-42. [CrossRef]

44. Fakeeha, A.H.; Naeem, M.A.; Khan, W.U.; Abasaeed, A.E.; Al-Fatesh, A.S. Reforming of methane by $\mathrm{CO}_{2}$ over bimetallic $\mathrm{Ni}-\mathrm{Mn} / \gamma-\mathrm{Al}_{2} \mathrm{O}_{3}$ catalyst. Chin. J. Chem. Phys. 2014, 27, 214-220. [CrossRef] 